Claremont Colleges

Scholarship@ Claremont

CGU Theses \& Dissertations

CGU Student Scholarship

2006

\title{
Remembering Danzig and Reclaiming Gdańsk
}

Jesse Lorber

Claremont Graduate University

\section{Recommended Citation}

Lorber, Jesse. (2006). Remembering Danzig and Reclaiming Gdańsk. CGU Theses \& Dissertations, 10.

http://scholarship.claremont.edu/cgu_etd/10. doi: 10.5642/cguetd/10

This Open Access Master's Thesis is brought to you for free and open access by the CGU Student Scholarship at Scholarship @ Claremont. It has been accepted for inclusion in CGU Theses \& Dissertations by an authorized administrator of Scholarship @ Claremont. For more information, please contact scholarship@cuc.claremont.edu. 


\title{
Remembering Danzig and Reclaiming Gdańsk
}

by

\author{
Jesse Lorber
}

Presented to the Graduate Faculty of Claremont Graduate University in partial fulfillment of the requirements for the degree of Master of Arts in

History

We certify that we have read this document and approve it as adequate in scope and quality for the degree of Master of Arts.

Faculty Advisor- Janet Brodie, Claremont Graduate University

Faculty Reader- Hans J. Rindisbacher, Pomona College

Faculty Reader- William Jones, Claremont Graduate University 


\section{$\underline{\text { Table of Contents }}$}

Acknowledgments...................................................................

Introduction and Literature Review...............................................1

Danzig Before 1945...............................................................11

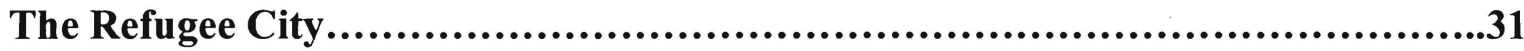

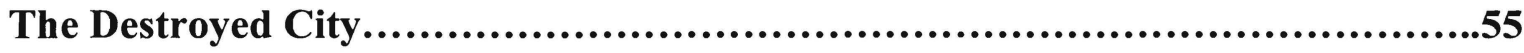

The Reclaiming of Gdańsk..........................................................76

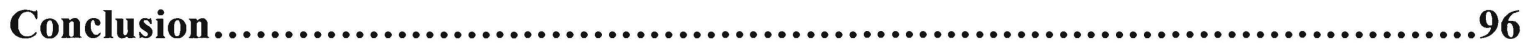

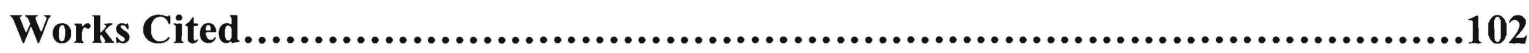




\section{Acknowledgements}

I would first like to thank my thesis committee members, Hans Rindisbacher and William Jones, as well as my academic advisor Janet Brodie, for all their valuable time and assistance throughout the advising, research and writing process, which has spanned the last seven months. I would like to thank Mr. Siegfried "Fred" Lehmann and Mrs. Łajica Lewandawska who allowed me to interview them, for their fascinating life stories, personal inner strength, and huge contribution to this project. I am greatly indebted to Łajica's grandaugher, Kay Lewandawska, who both organized and translated the interview. I would also like to extend my gratitude to my professors, classmates and colleages in the history departments of Claremont Graduate University and Claremont McKenna College and the German and Russian Department at Pomona College for inspiration, motivation, and shared academic interests. Last but certainly not least, I couldn't have finished my Masters Thesis without my family. Thanks for always being there and supporting me in whatever I have chosen to do. 


\section{Introduction and Literature Review}

Memories of the brutality of World War II in Germany and Poland focus heavily on the victimhood and suffering of human beings as a result of the war. However, during this war, many ethnic groups were traumatized by specific incidents or dynamics within society. Yet, the memory of a singular traumatic incident often has multiple versions, depending upon the ethnic background of both the perceived victim and perpetrator. A tragedy can be remembered in many different ways and the roles of perpetrator and victim are sometimes blurred. Possession of traumatic memory is further compounded by the fact that during World War II, ethnicity in this region was diverse and not always clearly defined.

The city once called Danzig, now named Gdańsk is one such place, whose memory of multi-dimensional suffering during World War II is possessed by German as well as Polish national memory. In this paper, I will analyze Danzig/Gdańsk as a place where remembrance of suffering during, before, and after the war is constructed around feelings of German and/or Polish victimization as a result of the war. This thesis will go beyond a re-creation of a space of shared traumatic memory that was the "traumascape" of Danzig/Gdańsk between 1935 and 1945 and invite the reader to consider the multiple versions of traumatic memories possessed by Germans and Poles who lived in and around Danzig during the war and suffered as a result. I would argue that the most significant aspect of the history, accounts, interviews and personal statements of German and Polish residents of Danzig/Gdańsk is a tendency by individuals who witnessed and perhaps survived the war, to consider only their own ethnicities' suffering at the hands of 
both the Nazis, the Red Army and Polish communist authorities, instead of a shared concept of victimhood. Between 1935 and 1945, whether this traumascape was called Danzig or Gdańsk, Germans and Poles were both perpetrators and victims of suffering, despite the predominant memory of those living there that could not or would not conceive of any victims of World War II, other than themselves. Ultimately, what conceptually separates the city of Danzig from the city of Gdańsk, beyond its complete destruction and re-construction, are the memories of suffering and trauma by those in the region, often defined by ethnicity, gender, and religion.

This thesis will highlight a number of traumatic memories chronologically in the history of this city. The Versailles Conference will be the beginning of the tale of these two cities in the first chapter, Danzig before 1945. The history of the interwar years reveals a severe rift between Poland and Weimar Germany over the Free city of Danzig. German memory would remember the city's nazification, the invasion by Germany and even the relative safety during the war as traumatic through a general feeling that Nazism had been forced upon German Danzigers, resulting in their own versions of victimhood. On the other hand Polish memory of the inter-war period of Danzig would move from memories of economic prosperity following the polonization of the Polish Corridor, to notions of victimization at the hands of the Nazis, which escalated considerably during and after the German invasion of Danzig in 1939, eventually resulting in population transfer. German memories of Danzig in the early months of 1945 , in the chapter The Refugee City, reveal the city as a refugee outpost and evacuation point in the grip of a pre-traumatic terror syndrome, whose German victims could not understand their own suffering, embodied in the fear of the Red Army and Soviet acts of reprisal in the east, as 
being caused directly by their own participation in the Nazi regime. This dynamic continues in The Destroyed City, when German suffering was greatly expanded by violence, robbery and rape at the hands of the Red Army. It is no surprise that Polish memory of the years prior to and during the war would focus on the increasing German repression of Poles in Danzig, through forced labor, germanization and population transfer. However, Polish memory of the rebuilding and reclaiming efforts discussed in The Reclaiming of Gdańsk, after the city's capitulation to the Soviets, found justification in their role as perpetrators of traumatic incidents, through memories of victimization at the hands of the German majority of the city prior to 1945 . German memory of victimhood in the post-war period would now reflect an experience of suffering, similar to what the Nazis had perpetrated against the Poles prior to the fall of Danzig.

This study will not focus extensively on Jewish memory of Danzig during World War II because the history of Jewish suffering in Danzig mainly ends prior to the German invasion in September of 1939. Stutthof concentration camp, outside of the city was not a major Jewish extermination center until the end of the war. Recent research has even disproved the widely held belief that Stutthof had supposedly delivered Jewish corpses from the camp to the Danzig Medical Institute where they were processed into soap. ${ }^{1}$ Without detracting from the victimization of those Danzig Jews who did remain in the city after 1939 and suffered during the war, Danzig's small Jewish community did not endure the hardships most other German and certainly Polish Jews in the east did. To call any group of Jews or other Holocaust victims historically lucky would be very difficult to morally substantiate. However, as this analysis will show most Jewish

\footnotetext{
${ }^{1}$ Joachim Neander, "The Danzig Soap Case: Facts and Legends", German Studies Review Vol.XXIX, Num. 1, February 2006, 63-68.
} 
Danzigers took the option to escape the city before the war with the help of the British and without being hindered by extra Nazi brutality, beyond having to sell their possessions. The Jewish communities of Berlin, Munich, Warsaw, and Prague were by and large not given such an option. The importance of the memory of the repression and extermination of Jews in the city in this analysis is in its relation to memories of German Danzigers who themselves retained a traumatic memory of guilt for not aiding Danzig's Jews in their time of need.

Just as the city itself was once shared by Germans and Poles, the historical interpretations of World War II's impact on the citizens of Danzig/ Gdańsk represent a multitude of contradictory viewpoints. While a great deal of material exists on the Free City of Danzig as well as the political upheaval in modern communist Gdańsk, very little has been written specifically about the political, military, or social history of Danzig or Gdańsk during the World War II era. Overall the historiography of Danzig, reflects the wider values of West-German, East-German, and Polish post-war society on the topic of self-victimization

While scholarship written prior to World War II on the history of the city tended to focus on the Free City of Danzig's economic history and current political development, it would not be until after the war, that notions of victimhood based on ethnicity became germane. In the post-war era of the late 1940s and early 1950s in West Germany, scholarship on Danzig found its place within the popular public memory of the war that generally emphasized German victimhood. This paradigm is reflected within the memoirs and accounts in Theodor Schieder's and Hans Rothfels's highly controversial 
Documents on the Expulsion of the Germans from Eastern-Central Europe, published by the Ministry of Expellees between 1953 though 1964, which included Danzig in its examination. These collections of the accounts of expellees from all over Europe and parts of the U.S.S.R, provide testimonies of people who lived or were staying in Danzig during 1945, describing the emotions that those individuals felt. Schieder, himself a former Nazi supporter, has had his work questioned for inaccuracy, virulently anticommunist right wing partisanship, and reactionary nationalism. Schieder stated that the documents were written to “...make the world aware of things that until now have been for the most part hushed up." He believed that the international community had wanted to silence German suffering, in favor of a forced sense of collective guilt which stressed German perpetration of war crimes. ${ }^{2}$ Cataloging of German victimhood continued into the 1960s when the Federal Ministry for Expellees, Refugees, and War Victims in Bonn released an extensive pamphlet in 1964 which calculated and organized German loses in the east, including Danzig, with precision. The trend of primary sources on Danzig and other former German spaces of memory in the east focused exclusively on German losses into the early 1960 s.

On the other side of the Iron Curtain, authorities in both Poland and EastGermany were very critical of such notions of German victimhood, as was reflected by historical scholarship and analysis on Gdańsk from the communist east during this time. While in West Germany, German refugees from Danzig and elsewhere were called Vertriebene or "Expellees," in East Germany they were dubbed Aussielder or "Re-

\footnotetext{
${ }^{2}$ Robert G. Moeller, War Stories, (Los Angeles: Univ. of California Press, 2001), 57-63.
} 
settlers" in subscribing to communist vernacular, which downplayed Soviet guilt. ${ }^{3}$ In communist Poland, the word "Danzig" itself was illegal and discussion which reflected upon the traumas that occurred in the city at the hands of both the Soviet Union and Poland at the end of war was considered taboo. ${ }^{4}$ In the early 1960s, the Polish communists produced a number of tourist pamphlets to celebrate the completion of the rebuilding of Gdańsk. In their brief assessment of the city's history, the word Danzig was omitted and any description or analysis of the city's German history was intentionally downplayed. Refusal to allow a more accurate and multi-sided discussion or analysis of Gdańsk would continue until the liberalizations in the communist world in the 1980s.

By the mid-1960s West-German modes of memory were being reworked to include admission and acceptance of guilt. Discussion of German suffering was relegated to the voices of reactionary politics, in favor of discussions which sought to accept and mend the trauma inflicted upon the victims of the Nazis. Philosophers such as Theodor Adorno, Alexander and Margarete Mitscherlich, as well as Hannah Arendt were very critical of West German society's and government's overall denial of their recent past. While historical scholarship specifically on Danzig remained scant during this period, fiction writer Günter Grass, one of the most significant voices in the history of the city, began writing his “Danzig Trilogy,” Die Blechtrommel (The Tin Drum, 1962), Katz und Maus (Cat and Mouse, 1963) and Hundejahre (Dog Years, 1965). Grass's writings

\footnotetext{
${ }^{3}$ Robert G. Moeller, “Germans as Victims? Thoughts on a Post-War History of World War II's Legacies," History and Memory, (Indiana Univ. Press, 2005), 11.

${ }^{4}$ Bożena Shallcross, "The Archaeology of Occcuptation: Stephan Chwin's Writings on Danzig/Gdańsk," Framing the Polish Home: Postwar Cultural Constructions of Hearth, Nation, and Self, (Athens, OH: Ohio State Univ. Press 2002), 117.
} 
go beyond insight into the diversity, personality, and fears of the city's residents and serve as an allegory for the conscience of West Germany during the 1960s. Grass's work seems to have been generally accepted by the academic community as factually driven from the perspective of an eyewitness of the rise and fall of Nazism in the city, though he himself did not witness the ultimate destruction of Danzig and the birth of Gdańsk.

The literature on Danzig/Gdańsk during the 1970s and early 1980s also displays a continuation of the acceptance and study of German guilt. The year 1970 marked the twenty-fifth anniversary of the end of the war and end of the Holocaust. That same year Herbert Levine published his work on the rise of Nazism in the Free City and the suffering of Jews under the Nazis. A decade later the Jewish Museum in New York, would show an exhibit on the history of Danzig Jewry. By the late 1980s and 1990s the debate on how to remember the suffering of the war began to emerge within a dynamic of shared experience and scholarship emerged which suggested that the war had victimized Germans, Jews, and Poles in unique ways, and that these sufferings could be juxtaposed. As the Eastern Bloc began to crumble, scholarship by historians in the east displayed a more accurate history of the city. The "Liberalization of Scholarship" under Premier General Jaruzelski facilitated this in Poland during the 1980 s. ${ }^{5}$ Nonetheless, communist authorities were unwilling to allow a complete liberalization of censorship on the memory of Gdánsk. For example, although Grass had a good relationship with the government of communist Poland for his stance on the Oder-Neisse line decision, his most influential work, Blaszany bębenek (The Tin Drum), was not published there until

\footnotetext{
${ }^{5}$ Carl Tighe, Gdańsk: National Identity in the Polish-German Borderlands, (London, UK: Pluto Press, 1990), xix-xx.
} 
1983 and its Polish translation continued to name the city "Gdánsk," though Grass had written it as "Danzig."

In the last twenty-five years, interest in the history of Danzig/Gdánsk has grown tremendously throughout the historical world in conceptualizing modes of remembrance. In 1990, Carl Tighe produced the most comprehensive English language history of the city. His work, titled Gdańsk/Danzig sought to connect the city to the larger arena of East Prussia and Pomerania, both of which possessed a shared German and Polish heritage. A more recent epistemological trend in the scholarship on this period has promoted the idea of "working through," as a method of reading, writing, and thinking about shared histories of suffering as a result of World War II. This concept has different definitions depending on the scholar, but ultimately it refers to the process of working through all the material of controversial topics such as suffering associated with the end of the war and not simply examining German, Polish or Jewish suffering exclusively. German post-war scholars such as Robert Moeller have suggested that “Aufarbeitung” or the concept of working through German history should encompass writers of both fiction and non-fiction in portraying a constructive history which seeks to improve present memory, by considering all angles of a topic such as traumatic history. ${ }^{7}$ Moeller, in his 2001 book War Stories: The Search for A Useable Past in the Federal Republic of Germany, as well as several subsequent article publications researched the memory of German suffering in Post War Germany, asserting that it is possible and ethical to write a

\footnotetext{
${ }^{6}$ Ibid, 277-281.

${ }^{7}$ Robert Moeller, "Sinking Ships, the Lost Heimat and Broken Taboos: Günter Grass and the Politics of Memory in Contemporary Germany." Contemporary European History Vol. 12, (NY: Columbia Univ. Press, 2003), 180.
} 
military history of the war's end in "which Germans caused immeasurable suffering and Germans suffer immeasurably."8

With the fall of communism discussion of previously controversial topics such as the history of Gdánsk, were no longer subject to censorship. Polish fiction writer Stefan Chwin brought his story Hanemann, later translated to English as Death in Danzig, to the international literary scene in 1995 , painting a history of the city from the perspective of Polish memory. Recent secondary literature from Poland tends to discuss Gdánsk within the entire scope of cities of shared memory at the end of the war. Polish historian Bernadetta Nitschke's 2004 publication, translated into German as Vertreibung und Aussiedlung Der Deutschen Bevölkerung aus Polen 1945 bis 1949 is the most recent and most comprehensive scholarly work which includes Gdánsk in its assessment of post-war history. In terms of specific history on Gdánsk, Sylwia Bykowska’s 2005 article “Gdańsk-miasto (szybko) odzyskane” (“Gdánsk a city (quickly) recovered”) in the Polish journal Biuletyn Instytutu Pamięci Narodowej, divulged a more complex and encompassing history of the city, in examining the motivations and memories of the Polish re-claiming efforts after the war's end suggests that Polish authorities were also perpetrators of trauma.

Within the last few years, historical research in English on cities such as Gdańsk, Szczecin, Wrocław, and other places of shared Polish and German memory has been pursued extensively. Following his seminal multi-volume work God's Playground: A History of Poland, Norman Davies published a study in 2002 entitled Microcosm: Portrait of a Central European City, which focused on the history of Breslau/Wrockaw as an example of a place of shared German and Polish memory. One recent trend among

\footnotetext{
${ }^{8}$ Moeller, "Germans as Victims? Thoughts...," 5.
} 
historians such as Elizabeth Clark and literary experts such as Joanna Stimmel has been to look at the visual evidence of the destruction of Danzig, and the rebuilding of Gdańsk, formulating the idea that the traumatic memory of the Danzig's destruction should be considered part of a shared catastrophe. Both scholars are interested in material and architectural history and in examining the city's complex and violent history. Their studies, based mainly on modern Polish history and literature respectively, are among the first attempts to examine the history of this city, specifically through modes of trauma remembrance as shared memories between Germans, Poles, and Jews in Danzig/ Gdańsk. What is lacking from the literature is a serious consideration of the history of Danzig/Gdańsk and the ways shared memories of victimhood were constructed by Germans and Poles. A study which looks at actual descriptions and memories of suffering and victimhood in order to attain a true sense of the traumascape in Danzig/ Gdańsk between 1935 and 1945. In a place like Danzig or Gdańsk, where the very definitions of perpetrator versus victim or Germans versus Pole are blurred, working through all versions of traumatic memory is necessary in formulating a complete history of the end of the city once named Danzig and the rebirth of the city now called Gdańsk. 


\section{Danzig Before 1945}

With the passing of World War I, Danzig had experienced a hundred years without being directly involved in, a witness to, or affected by any sort of significant trauma, a fact of which few major cities in Eastern France, Belgium, the Netherlands, Germany, and Poland could boast. Danzig's port was mainly used in support of the eastern front and the city witnessed no combat, destruction, or significant loss of life. While Danzig was of minor importance in the Great War's military history, its importance as an item on the diplomatic agenda of the post-war decision-making process was key. The decision to establish the Free City of Danzig, separated from Germany by the Polish Corridor to the Baltic Sea, was not popular with the ethnic German residents who comprised ninety-five percent of the population of Danzig. The inter-war period in the Free State was marked by economic and ethnic competition between Poland and Danzig. Worldwide depression, increased economic competition and fear of polinization in Danzig, all resulted in economic support and relief from Weimar Germany, which led to the nazification of Danzig politics. International scrutiny of the Free State grew soft during the 1930s due to the perception that the region problems had stabilized, resulting in the complete nazification of Danzig politics, whose first victims were Danzig's Jewish community

Though separated geographically from Germany, it is accurate to say that Danzig's government, politics, and most residents were under the control of the Nazi party by 1935 . The Free State of Danzig still existed as a politically autonomous entity. Danzig was Hitler's first military target and the first battle of World War II took place in 
the streets and harbors of the city. Just as Germans in Danzig had actively supported the nazification of Danzig's politics, they were equally complicit in the invasion as the German population knew preemptively that Hitler was going to invade their city. Danzigers also did not come to the aid of the Polish military targets in the city. After takeover, nazification of the city's population, as well as the complete transformation of Gdynia, Danzig's former competitor to the north, became the new priority for the Nazis. Danzig by and large was not affected by the ravages of World War II until 1945, allowing the German authorities to pursue a racially homogonous Gau of Danzig-West Prussia.

Despite these historical realities, memories of both Germans and Poles, born and raised in Danzig during the inter-war period and recorded as adults after the war, focus on establishing their innocence in the nazification and invasion of the Free City and their own victimization at the hands of the Nazi authorities. Accounts and interviews of individuals who lived in the Free City during the inter-war period describe it as a place where Germans and Poles lived in harmony, despite political tensions between Weimar Germany, Poland and Danzig. Positive memories of this period change into memories of personal victimization at the hands of the Nazis during the outbreak of World War II in Danzig. Both Germans and Poles remembered the invasion of the city as something that was forced upon Danzig, where working class people of both ethnicities suffered. It is not surprising that memory of those Poles who remained in the city focuses on their own suffering through forced germanization and population transfer. What is surprising is that Germans living in Danzig, which by all accounts must have been one of the safest and least war-torn places in the Third Reich, retained a traumatic memory of the war 
years prior to 1945. Even though they enjoyed the status of the dominant ethnic group in a secluded military position, German memory from this time had a predictive quality which foresaw that Danzig Germans would one day bear the brunt of the suffering at the war's end, following the unavoidable defeat of Hitler.

The Allied powers came to the Versailles table in 1919 fully convinced that a strong and independent Poland was the only way to check future German aggression. Granting Poland access to the sea was seen as crucial to giving the country the ability to fill its newly conceived role and donating Danzig to Poland seemed the most obvious solution. Wilson had proposed this idea within the Fourteen Points and was supported by Clemenceau, only the British delegation was hesitant to support so drastic and permanent a solution in such a multi-ethnic region. In 1918 the British Foreign Office had already declared that "for the sake of Poland's own future, we must firmly oppose exaggerated Polish claims." British skepticism for simply giving Danzig to Poland, led to the alternative plan by James W. Headlam-Morley to create a completely autonomous Free City protected by the League of Nations. ${ }^{10}$ Poland was given a corridor to the sea, cutting Danzig off from Germany, which for the Poles was at least a half victory and gave them an opportunity to pursue Danzig in the future. Most important for Poland was the continuation of its export up the Vistula, without toll or hindrance, as well as to stay connected to the Baltic shipping economy. With the creation of a corridor, the Poles

\footnotetext{
${ }^{9}$ Christopher M. Kimmlich, The Free City: Danzig and the German Foreign Policy, (New Haven, CT: Yale Univ. Press, 1968), 3-4.

${ }^{10}$ Ibid, 10.
} 
realized that export did not necessarily need to go through Danzig anymore and that "Danzig needed Poland, more than Poland needed Danzig." 11

When the Allied powers ratified Section XI of the Treaty of Versailles on 10 January 1919, the city became known as Freie Stadt Danzig to Germans and Wolne Miasto Gdańsk to Poles. However, the latter of these two ethnic communities was vociferously outraged at the results of Versailles. In March of that year 70,000 to 100,000 Danzigers rallied to protest the separation of their city geographically from Germany proper. ${ }^{12}$ A rally of that size, approximately a quarter of the city's population, reveals a general sentiment of Danzigers' dislike of the results of international peacemaking, while simultaneously showing affinity and continued support for Germany, the same country which had aggressively instigated, exacerbated, and pursued the last war, causing the death of hundreds of thousands of Germans across Europe. Though few in Danzig had any idea of what it was like to have a city shelled or burnt, to have the young male populations of entire neighborhoods and hamlets listed as casualties of war, or to have women raped by marauding soldiers and fewer still had any recollection of the last time any sort of storm of violence had rained down on Danzig.

The law of Danzig was to be enforced by the League of Nations, independent of the Weimar Republic and Poland, but this was hardly the case. Protection of Danzig and its German population was supremely important to Weimar foreign policy and managed to influence politics in the Free City. For instance, career bureaucrats from the Weimar government dominated the civil service of Danzig throughout the interwar period. Also,

\footnotetext{
${ }^{11}$ Elizabeth Clarke, "Reshaping the Free City: Cleansed Memory in Danzig/Gdansk, 1939-1952," Ethnic Cleansing in Twentieth-Century Europe, (Columbia University Press, NY 2003), 3.

${ }_{12}$ John B. Mason, The Danzig Dilemma: A Study in Peacemaking by Compromise, (Stanford, CA:

Stanford Univ. Press, 1946), 6.
} 
during times of economic hardship in Danzig, especially during the world-wide depression of the 1930s, Germany consistently stepped in to provide economic relief to Danzig, so that nothing could diminish the precious sense of Deutschum or perceived cultural, linguistic, and national connectedness to Germany, which the city was trying to retain. Throughout the 1920s, Danzig remained economically dependent upon foreign aid, mainly from Germany. Political and economic problems in Germany in the wake of Versailles played out in a similar, though much smaller scale in Danzig. ${ }^{13}$

The Free City of Danzig was supposed to be a model of inter-ethnic co-operation and co-habitation with Poland where Germans and Poles were to live in economic and political harmony, though this was hardly the case. As a result of the Russo-Polish War in 1920, the city's trade with Poland was non-existent, causing a major depression there. Almost immediately after the end of the war, Poles began buying up property in Danzig on a large scale as property prices had dropped considerably. German anti-Polish agitation was ever present and increasing during the Free City period, often manifesting itself in slowing down and sabotaging the Polish exports, going through the city. Germans in Danzig felt particularly threatened by the Polish Post Office which opened in 1920, Polish control of the railroad, and the Polish garrison on the Westerplatte, as they were all constant reminders of Poland's omnipresence in the city. By 1930, the Polish population of Danzig grew to about 50,000, eighty percent of whom were members of community associations, cultural institutions, or subscribed to newspapers for Poles. Relations between Warsaw and Danzig deteriorated, particularly in 1923 when Lithuania

${ }^{13}$ Ibid, 29-53. 
seized the city of Memel. Rumors that Poland would do the same to Danzig reached Berlin and troops were mobilized on both sides of the border. ${ }^{14}$

Economic competition between Danzig and Poland led to increased polonization of the Polish Corridor, particularly through the economic development of Gdynia. After a decade of struggling to share the port of Danzig with German dominated interests in the city, the Polish government encouraged the expansion of the port of Gdynia, ten miles to the north. ${ }^{15}$ The Polish Corridor by this time had been heavily polonized and many Germans had already been squeezed out of both Gdynia and the Corridor. ${ }^{16}$ What was once a tiny fishing village in 1920 was transformed into a prosperous port, which by 1930 exceeded Danzig by twice the tonnage of both imports and exports. With the development of the port of Gdynia, Poland no longer had to rely on the hostile Danzigers to export its goods. The Poles used Gdynia to harass and rival Danzig, to the point where the League High Commission had to step in and establish trade quotas to ameliorate the situation. ${ }^{17}$ By 1933, Gdynia had become Europe's ninth largest port and any trade up the Vistula to Danzig was done merely to fulfill international quotas. ${ }^{18}$

The political and economic realities of the inter-war period in the Free State of Danzig would suggest that a severe rift existed between the German majority and Polish minority in Danzig. However, the memories of residents who were children during this period suggest that Germans and Poles lived in harmony with one another. Łajica Lewandowska, a Pole born in Danzig in 1929, stated that although her family was ethnically Polish, they usually spoke German and that she didn't even start to speak

\footnotetext{
${ }^{14}$ Tighe, 104-105.

${ }^{15}$ Mason, 105-109.

${ }^{16}$ Tighe, 92.

${ }^{17}$ Mason, 109-125

${ }^{18}$ Tighe, 104-105.
} 
Polish until after the war. Growing up she went to a school where both Germans and Polish teachers taught a class of German and Polish students in German. Lewandowska stated that "Before the war everyone lived peacefully." 19 Likewise, the account of Gisela Lehmann, an ethnic German born in 1933, recalled that growing up during this period in Danzig was a positive experience, "without many troubles." ${ }^{20}$ Both the memories of Lehmann; a German and Lewandowska; a germanized Pole, seem to emphasize that ethnic tensions in Danzig did not exist, despite growing political strife between Germany and Poland, with the Free City of Danzig in the cross-fire. These positive memories of the interwar period would later turn into notions of victimization at the hands of Nazis during the beginning and the end of the war in Danzig.

Throughout the 1930s Danzig was dependent on German trade, diplomacy, and political direction more than ever. Economically, Danzig was doing more business than it had in two decades, despite diminished trade with Poland, because the German government guaranteed a certain amount of business to go through the city's port as a supplement. ${ }^{21}$ The worldwide depression in the 1930 s once again required Germany to aid Danzig economically, which simultaneously allowed Versailles revisionism to flourish. This decade witnessed a never ending attempt by both the governments of the Weimar Republic and Danzig to revise the ruling on its Free State status in the Versailles settlement. Several times the League of Nations rejected referendums from the people of Danzig to return to Germany proper. Economic aid from Germany carried with it the disease of the growing right-wing political activism in the Weimar republic. The world

\footnotetext{
19 "Lajica Lewandowska interview," conducted by author, 3/14/06.

${ }^{20}$ Gisela Lehmann, "The Developments leading up to our forced resettlement from our original homeland," (Köln, 1950), 1. .

${ }^{21}$ Mason, 26-101.
} 
began to see Weimar revisionism and the rise of National Socialism as part of the same problem, causing any questions concerning the return to Germany of Danzig or the Corridor to be suspended. ${ }^{22}$

While the history of National Socialism's growth in the Free City of Danzig is not unusual to any German city at this time, most Germans in Danzig seemed to embrace Nazism enthusiastically. Mirroring the Weimar republic, The Free City's political arena was awash with different political parties and affiliations. The early Völkish parties found their place in Danzig politics, along with the communists, centrist Catholic, and polish parties. The main challenge for right wing politics in the 1920s was internal bickering and power struggles, mirroring those in Munich at the time. ${ }^{23}$ Albert Hohnfeldt is generally credited for initially bringing Nazism to Danzig. A native of Danzig, Hohnfeldt left his home to participate in the "Beer Hall Putsch" of 1923 in Munich and returned two years later to form a Danzig wing of the SA. It was not until 1930, that Herman Göring installed Albert Forster to guide National Socialism in the Free City, naming him Gauleiter of the Danzig Nazi party. Known for his powerful oratorical skills, Forster, who despite not a being a native Danziger but a Bavarian, was successful because he implemented elements of National Socialism from Germany, which had been the base of much of Nazi political success up to this point in the Free City, while avoiding international attention to the growing city's right-wing. Forster brought with him youth movements, the Danziger Vorposten propaganda newspaper and support from the rural districts within the Free State. Forster also encouraged street warfare against communists, Jews and Poles. It could be said that Forster's most important tactic in

\footnotetext{
${ }^{22}$ Kimmlich, $160-166$.

${ }^{23}$ Herbert Levine, Hitler's Free City: A History of the Nazi Party in Danzig, 1925-1939, (Chicago, Ill: Univ. of Chicago Press, 1970), 18-30.
} 
gaining support in Danzig, was that he made the Danzig Germans believe that Hitler cared about the city and made them believe him. On the eve of the 1930 election he united the squabbling right wing political groups in Danzig and led the Nazis to gain $16.1 \%$ of the vote in the Danzig Senate $\left(18.3 \%\right.$ in the Weimar election of that year). ${ }^{24}$ The German-Polish Non-Aggression Pact of 1934, which outlined peaceful relations between these two nations was the key event in dictating the future of Nazi dominated politics in the Free City of Danzig. Hermann Rauschning, who the Danzig Nazi party had elected to be its chairman and to serve as the city's Senate president, signed an agreement with Polish Premier Józef Piłsudski to guarantee that Polish language, culture, and education in the city would be preserved, and that the rights of both Catholic and Jewish citizens of Poland be maintained. In return the Poles agreed to a more equitable split of the commerce coming up the Vistula River. The League of Nations witnessed this seeming act of good will as a sign that this region and its ethnic and national questions had been resolved. Following the Non-Aggression pact the League unofficially phased itself out of any current or future arbitrations processes between Poland and Germany over Danzig. ${ }^{25}$ This allowed the Nazis in the city to use increased street violence against their opposition in the 1935 election, in which the Nazi party took the majority of the Senate. Immediately, laws banning opposition parties and repression of the rights of Poles and Jews, public segregation, and legal restrictions emerged. ${ }^{26}$ By the later part of the 1930s, Danzig politics was firmly under the thumb of Hitler. The League made no official comment or response to this violence and results of the election and it seemed as if both the League and the Polish government washed their

\footnotetext{
${ }^{24}$ Ibid, 31-35

${ }^{25}$ Ibid, 53-69.

${ }^{26}$ Ibid, $81-121$.
} 
hands of the Danzig issue. At this point the Free City of Danzig was free only in name and the politics and authority of Berlin would now determine its future course of the city.

Now that Danzig politics and law were determined by Hitler, Nazi authorities in the city soon began initiating a policy of Gleichschaltung, the process of nazification, whose first target was Danzig's Jewish population. Since Kristallnacht in Danzig on 12 November 1938, a few days after it had transpired in Weimar Germany, Nazi authorities in the city made it their agenda to force most of the 6,000 Jews in Danzig ( $2 \%$ of the city's overall population) to leave prior to the invasion. Following the enactment of the Nuremberg Laws in Danzig later that month, Danzig's Jews faced constant harassment and laws which sub-humanized them, causing Jewish emigration from the city to begin. The first Jews to leave were those with Polish citizenship, who had the ability to simply move a few miles away from Danzig to the Polish Corridor. On 17 December 1939, 2,000 gathered at Danzig's Great Synagogue and were convinced by Rabbi Hermann Segall to flee the city. He had been contacted by Nazi officials and told that if the Jews of the city did not leave immediately they would be subject to worse treatment. Segal convinced his congregation that with guaranteed help from the British, Danzig's Jews would be transported to Palestine. Though they would have to pay for their own transfer from the city, Forster himself had promised the Rabbi that they would not be molested if they left Danzig. ${ }^{27}$ On 3 March 1939 the first transport of five-hundred Danzig Jews left for Palestine, without any problems. When Danzig was invaded in September only seventeen-hundred registered Jews were left in the city, most of whom were elderly and eventually transferred to Theresianstadt concentration camp. ${ }^{28}$ While Stutthof

\footnotetext{
${ }^{27}$ Ibid, 126-135

${ }^{28}$ Levine, 137-138.
} 
concentration camp, which had existed several miles east of Danzig since 1939 would have been the likely destination for the handful of Jews who remained, this camp mostly served to imprison and liquidate Poles from the region, as well as interned Soviet and British POWs. In fact Nazi authorities did not designate Stutthof as a major internment or extermination center for Jews until $1944 .^{29}$

One eyewitness to the repression of Jews in Danzig in the 1930s is Günter Grass, who simultaneously blames Danzigers, especially Christian clergymen, for allowing the repression of the city's Jews, while retaining his own sense of victimization for being complicit in the Holocaust. In his 1980 essay entitled "What Shall We Tell Our Children," Grass recalls, growing up in the Danzig suburb of Langfuhr, the day when the SA burnt down the synagogue which was on the same street as the Church of The Sacred Heart, where he served as an alter boy when he was not participating as a loyal Hitler Youth. Grass remembered his bishops and priests standing by and remaining silent on the repression of their fellow Danzigers and fellow human beings. They did not even utter a word of disgust for the anti-Semitic violence, or a prayer for the victims. He writes, "Individual Christians and Christian groups share the utmost bravery in resisting Nazism, but the cowardice of the Catholic and Protestant churches in Germany made the churches inactive accomplices. ${ }^{30}$ As a Danziger he works through the trauma of how he and his family, neighbors, friends, and fellow Christians could stand by and allow such a thing to happen. Grass's accusations firmly place the blame on both the lay population, and on the Danzig clergy in there compliance with Nazism.

\footnotetext{
${ }^{29}$ Alexander Braun, "History," Państwowe Muzeum Stutthof website.

${ }^{30}$ Günter Grass, "What Shall We Tell Our Children," Danzig 1939: Treasures of a Destroyed Community, (Jewish Museum, NY: Wayne St. Univ. Pub, 1980), 21-22.
} 
Yet, Günter Grass retained a sense of suffering for the guilt of being a perpetrator in the Holocaust. He reported that later in life he suffered from nightmares because of this guilt. He writes, "I could not swear that had I been six or seven years older, I would not have participated in the great crime. My doubts were such that I was plagued (more and more often as time passed) by nightmares in which I felt myself to be guilty."”1 Most German and Polish witnesses to these events in Danzig, including Lewandowska and Lehmann, who are about Grass age's, stated that they were unaware of the crimes being committed against Jews until after the war. Their memory of the war focuses exclusively on their own suffering at the hands of the Nazis. Grass as an eyewitness rejects their innocence, emphatically stating that he and almost all other Danzigers young and old were privy to and often served as agents in the perpetration of Jewish victimhood. Grass's traumatic memories differ from standard German and Polish memory of the nazification of Danzig in that his acknowledges being a perpetrator, instead of a victim of the Nazis

Most German Danzigers surely sensed that Hitler would invade the city and return it to the Third Reich. On 31 August 1945, he notified the German foreign office in Danzig that military takeover of the city would begin the next day. ${ }^{32}$ Reportedly, anyone who ventured out into the street of Danzig early in the morning of 1 September would have seen German news reel crews setting up and waiting for something to film. Whether Polish citizens, civil service, or military in Danzig were privy to this advanced knowledge is not known; however, the Germans who had been made aware of the

\footnotetext{
${ }^{31}$ Ibid.

32 Tighe, 148-149.
} 
impeding invasion did nothing to stop the German military from striking them. The Schlesweg-Holstein fired on Polish warehouses on the docks, while German troops occupied the Polish operated railway station and customs office. The Poles locked inside the Post Office held out, until a battalion of SS-Heimwehr burnt out the resistance with flame throwers, executing all who surrendered. It took five days for the German army to subdue the Polish garrison on the Westerplatte. As Hitler and Forster formally announced the return of Danzig to Germany, Wehrmacht troops swept into the city, on route to reclaiming the rest of the Corridor and later Poland. Civilian casualty rates as a direct result of the invasion were minimal and those who died in the fighting were mainly Polish dock workers and civil servants. ${ }^{33}$

Both German and Polish memory of the events of 1 September 1945 focus strongly on trauma through victimization as working class Danzigers who stood against Nazi authorities in their annexation of the city. The memories of both a German and germanized Pole in Danzig who witnessed these events seem to emphasize that this invasion was something which Danzigers did not support and which caused them and their families a great deal of personal trauma. Gisela Lehmann recalled being awakened that day by shots and then witnessed her father's arrest by the Gestapo. He had refused to join the party and remained a member of a labor union until his arrest, which resulted in the loss of his rights as a citizen, his job at the railways, and his immediate drafting into the army. ${ }^{34}$ Lajica Lewandowska, who was eleven years old in 1939, experienced a similar set of traumatic memories that day. Her father, also a railroad worker was arrested on 1 September, for complaining about the German invasion of Danzig. He had

\footnotetext{
33 Ibid, 150-151.

${ }^{34}$ Lehmann, 1.
} 
fought for Germany during World War I and even had proof of his veteran's status with him as he was taken to prison. Nevertheless, he was detained for three weeks, causing him also to be fired from his job. ${ }^{35}$

While the Lehmann and Lewandowska families possess traumatic memories of the invasion of Danzig, which they opposed and suffered for as a consequence, most citizens remained passive during Hitler's invasion. No records or reports indicate that the people of the so called Free city offered any resistance to the soldiers storming the railroad, customs offices and government buildings, nor aiding the Polish resistance in the post office and Westerplatte garrison. In fact, Danzigers by and large seemed to welcome the invasion, considering that Hitler was greeted by thousands as a savior when he made his first official visited on 20 September. ${ }^{36}$ Yet, the memories of Gisela Lehmann and Łajica Lewandowska are an attempt in trying to distance themselves and their families from those Danzigers who welcomed the Nazis. Both accounts also describe 1 September 1939 as a day when both German and Polish working class people suffered. Yet the history of the city's invasion seems to indicate that working class people supported Danzig's return to Germany. The traumatic memories of both women's fathers have several commonalities. The city's railroad industry had been mainly manned and run by Poles, who as blue collar laborers were no doubt subject to leftist politics, making both men doubly suspect in the eyes of the German authorities, no matter what their ethnicity was. Both women's accounts stated their families didn't belong to any political parties or ethnic organizations and were completely apolitical, yet both had fathers who were arrested on this day for political reasons, causing their children to retain

\footnotetext{
${ }^{35}$ Lewandowska intervịew.

36 Tighe, 150-151.
} 
a traumatic memory of the 1 September 1945 . Perhaps the most significant commonality between the memories of Lehmann and Lewandowska is what they fail to remember or omitted when they were recorded as adults with post-war hindsight. Neither Lehmann's account, recorded as an expellee in Cologne in 1950, nor Lewandowska's interview in March of 2006, display any attempt to consider how their respective families may have been complacent towards, in denial of, or even played an indirect role in the nazification of Danzig.

As the Jews of Danzig had for the most part been eliminated as a significant presence prior to 1939, nazification efforts in Danzig focused much more on eliminating the Polish presence from the region. Danzig law had already succeeded in prohibiting Poles from owning motorcycles, cars, radios, telephones, and record players. Now, nazification was to be carried out throughout the newly formed Gau of Danzig-West Prussia to eliminate all evidence of Polish existence and prosperity. Beyond renaming Polish streets and towns, stripping Poles of their rights and eliminating the speaking or teaching of Polish, the German authority's prerogative of Gleichschaltung was the complete elimination of the Polish national element in all its forms and manifestations in the Gau of Danzig-West Prussia. ${ }^{37}$

The Nazi policy of Gleichschaltung faced the challenge of how to deal with Danzig's inherently multi-ethnic character. In Danzig the lines between who was German and who was Polish were not always clear, as many people had Germans surnames, but spoke Polish, or Polish names but spoke German. It terms of fulfilling their goals of an ethnically homogenous Gau of Danzig-West Prussia, the Nazi authorities pursued a policy of categorization along ethnic lines. They had little difficulty

${ }^{37}$ Levine, 154-157. 
in deciding the fate of Polish citizens and any Pole who had moved to Danzig-West Prussia after 1918 was transferred. This was true in other eastern Gaus and by the end of October of 1939, 30,000 to 40,000 Poles were expelled from Danzig, Pomerania, and the areas of the former Polish Corridor combined. ${ }^{38}$ Danzig was an ethnically peculiar place because its population included a small percentage of Kashubians, Kosnavians, and Masurians, Slavic groups native to the Baltic region that had been germanized over the centuries and had been interacting with, marrying, and living in close proximity to ethnic Germans and Poles. These mixed ethnicities embodied the less than clear-cut problem for the new hyper-germanization policy of the Nazi authorities. In their never ending pursuit of categorizing existence, the Nazis found ways to build a racial hierarchy, even in a place like Danzig. Generally these mixed ethnic groups were considered "Nichtdeutsche." Although this distinction placed them at the bottom of the racial pyramid, they were German enough not to be transferred, a situation in which they would again find themselves in the spring and summer of $1945 .{ }^{39}$

Gauleiter Albert Forster favored retaining some Poles for labor forcing them to in essence become German on paper. His policy of nazification by 1941 employed the process of screening the Gau's population according to Reich standards, followed by deportation of excess Polish and Jewish individuals, and the resettlement of Poles to the Wartheland, the General Government and the Baltic regions. ${ }^{40}$ Those Poles who were not deported were forced to apply for the German Volksliste, a national register of Germans in the region. Those who refused were threatened with imprisonment or

\footnotetext{
${ }^{38}$ Tighe, 165-166.

${ }^{39}$ Ibid, 166

${ }^{40}$ Elizabeth Harvey, Women and the Nazi East: Agents and Witnesses of Germanization, (New Haven, CT: Yale Univ. Press, 2003), 82-83.
} 
deportation. ${ }^{41}$ Łajica Lewandowska recalled that everyone she knew was declaring themselves German after September 1939. She stated that the Nazis categorized those on the Volksliste into a four class system of varying levels of "germaness." The fourth or bottom class was a grant of German citizenship given to Poles, which gave the government the option of revoking this privilege anytime without a reason, which would result in deportation. Lewandowska stated that she, her family, and most Poles were at the bottom of this list. Memories of the Volksliste went beyond mere feelings of alienation, also invoking memories of extreme violence against the Polish presence in Danzig. She noted that immediately following the invasion all Polish priests who had not fled the city were rounded up and shot instead of being placed on the Volksliste. As a deeply religious Polish Roman Catholic this traumatic memory in particular haunted Lewandowska. The memory of these dead clergymen, now immortalized by a statue in Gdańsk, remains with her to this day. ${ }^{42}$

One area in the Gau which the Nazis focused particular attention towards the nazification of was the renamed and reclaimed city of Gotenhafen. This city known to Poles prior to the invasion as Gdynia was completely built, modernized and made successful by the Polish interwar government, as its first true Baltic port. To the Nazi authorities it was a place of ridicule, distaste and un-cleanliness that needed to be reclaimed into the German cultural space. Dr. Richard Csaki of the Deutsches AuslandsInstitut had visited Gdynia in the spring of 1939 , prior to the invasion, in an undercover investigation of whether the city might one day be fit for German habitation. He found Gdynia, as the Poles had constructed it, to be a "Gigantomaniac" place of American-

\footnotetext{
${ }^{41}$ Bernadette Nitschke, Vertreibung and Aussiedlung Der Deutschen Bevölkerung aus Polen 1945 bis 1949, (Munich: R Oldenbourg Verlag, 2004), 139.

${ }^{42}$ Lewandowska interview.
} 
influenced institutional architecture. Margarete Blasche, a teacher from Schneidemühl, took a tour of Gotenhafen in 1940 and compared the boring Polish architecture with the beauty of Danzig's architecture and wrote that it was the product of "Capitalist spirit and soulless internationalism.” In 1941 a Nazi women's periodical called NS-Frauenwarte published an article by Renate von Steda, who reported how disgusting and vile confiscated Polish houses in the city were and that "gas had to be used to rid them of vermin before German people could be accommodated there." ${ }^{43}$

Gdynia had been reclaimed by Germans as Gotenhafen in accordance with Hitler's general policy of Lebensraum, but still had remained a gross codeword for Polish inferiority, un-cleanliness, and capitalist endeavors. Where the German culture of Danzig appeared to be orderly, rational, and tidy, Polish culture in Gdynia was industrial, disconnected, random, and disorderly. ${ }^{44}$ Interestingly, all these accounts refer to the city as Gdingen, the German translation of Gdynia and not the city's new name: Gotenhafen. This suggests that the writers of these statements felt that the city was still awash in the impurity of polonization, manifested in the physical state and appearance of Gotenhafen and that in order to reclaim the cultural space of this city, much more action would be required by Germans than mere name changes. The main result of this dynamic in Gotenhafen, as well as other places in the Danzig region was the dislocation or transfer of entire town populations in the areas of the Gau, which had formally been part of the Polish Corridor, to fulfill the reclaiming of space. ${ }^{45}$

Germanization through population transfer was not particular to Gdynia or the former Polish Corridor, and Polish memory of the interwar years in the city of Danzig

\footnotetext{
${ }^{43}$ Harvey, 125-129.

${ }^{44}$ Ibid.

${ }^{45}$ Ibid, 90.
} 
reflects this final stage of Polish victimization at the hands of the Nazis. Lewandowska's memory of her family's existence under the Nazis during World War II indicates that despite years of accepted germanization prior to 1939 and forced germanization immediately afterwards, Poles who remained in the city continued to suffer heavily. Although her father was eventually released from prison and able to find work at a shipyard outside the city, her brothers, ages sixteen and twenty-one, were sent to work in Germany. Her uncle, who had been forced to hide outside of Danzig as he had been a railroad official, was discovered and sent to a labor camp, causing his wife to commit suicide in $1943 .{ }^{46}$ Polish memory of the war indicates that suffering inflicted by the Nazis upon Poles who remained in Danzig was continuously evolving and resulted in the complete eradication of a Polish presence in the region through population transfer.

Although Danzig was a relative safe haven throughout most of the war, German memory of life in the city between 1939 and late 1944 expresses a sense of a pretraumatic stress syndrome within the city's seclusion and safety. Although Hitler had used it as a staging point in 1939 to take Poland and sweep up the Baltic coast as well as during Operation Barbarossa in 1941, Danzig was fairly untouched by the ravages of World War II. The city's port served as an assembly base for submarines, which were tested in the Bay of Danzig. In July 1942, the British RAF bombed the base with minimal damage to either the base or Danzig's production output. ${ }^{47}$ Beyond these isolated events, such as the occasional bomb raid, and the death of Danzig men who had died in combat, the city's Germans experienced little war-related tragedy. Nevertheless, Gisela Lehmann wrote that this sense of calm was subordinated to the trauma of her fear

\footnotetext{
${ }^{46}$ Lewandowska interview.

${ }^{47}$ Tighe, 178-179.
} 
of the impending doom in store for Danzig: "Until 1944 we were almost totally untouched by the bombing attacks on our old historic city. Only at the beginning of 1945 were we to feel the full impact of the inhuman unavoidable tortures of the war." Lehmann also noted that after her grandmother died in 1943, her mother and the priest consoling her, "Stayed at our home on long evenings while both him and my mother discussed the future and terrible end which was to befall us." ${ }^{48}$ Within these sentiments is a sense that the war in the east, like the takeover of Danzig itself, was propagated solely by Hitler and the Nazis and a prediction that the Germans in Danzig were going to suffer as a result of both. Lehmann's memories of the war years in Danzig do not consider that Germans in the city had allowed the Nazis to inflict suffering upon their Polish neighbors. Instead, the trauma of fear that the outcome of the war would surely end badly for the innocent Germans of Danzig prevails in her memories.

${ }^{48}$ Lehmann, 1 


\section{The Refugee City}

With the arrival of the winter of 1944 and the advance of the Red Army through East Prussia, Danzig and its then 404,000 citizens had already begun to witness an influx of eastern Germans fleeing the approaching eastern front. ${ }^{49}$ Even before January 1945 refugees, predominantly from the south of the Gau of Danzig-West Prussia, East Prussia and the Baltic region began swarming into the city to escape the Soviet invasion. By January, Danzig was the main rally point for refugees, fleeing west by land and sea. It was a relatively safe position in the crumbling east through the winter and early spring of 1945, despite the proximity of Danzig to the epicenter of the fighting and had suffered inconsistently from bomb raids until that point. Danzig was a place that refugees from the east felt they could live in safely or find transportation to interior regions of the Reich. Those refugees from other eastern German territories encountered great perils to flee to Danzig. Ultimately, tales of suffering by eastern German refugees, especially incidents of rape caused the refugees and citizens of Danzig to take extremely dangerous measures in order to escape the city. Like rape, rumors of the perils of evacuation by sea proved to be true for many unlucky refugees. On the other hand, most native Danzigers remained in the city and by and large made no attempt to leave until almost March, when the city's fall was all but imminent. This was the result of continued belief in Hitler and the German armies' ability to drive back the Russians. Loss of faith in the war effort and in the Nazi superstructure also caused rampant crime, profiteering, and an attempt by Germans to distance themselves from their guilt ridden past.

\footnotetext{
${ }^{49}$ Theodor Schieder ed., Documents on the Expulsion of the Germans From Eastern-Central Europe Vol.I The Expulsion of the German Population From the Territories East of the Oder-Neisse Line, (Bonn, Germany: Federal Ministry for Expellees, Refugees and War Victims, 1953), 34.
} 
Statistically speaking, Danzig, Gotenhafen, and the small port of Hela on the northeastern tip of the Hela peninsula, were the evacuation points to the west by both land and sea for 900,000 refugees in January alone. By May, long after the city had fallen, 300,000 additional refugees, wounded soldiers and civilians would leave the port. Whether it was known as Danzig or Gdańsk, the ports of this region evacuated 1,285,000 approximately, more than any other single city in East or West Prussia, or Pomerania. ${ }^{50}$ These figures alone demonstrate the importance of Danzig as a rallying point for refugees. Furthermore, these statistics suggest that it may have been common knowledge among German refugees that Danzig was a safe haven, worth enduring the hardships of the Baltic winter and Russian onslaught in an attempt to flee there in January and February 1945. It seems that Danzig had reached mythic status for refugees as a safe haven amidst the crumbling eastern front.

This false sense of safety which seemed to exist in Danzig during this time among both residents and refugees was promoted by a number of factors. Foremost, was the faith in Hitler and the Nazi regime among Germans in the east. Gauleiter Albert Forster had ordered the city to begin to reinforce its defenses in November of 1944 , confidently believing that if worse came to worst he would be able to defend the capital of his Gau until Hitler released his "secret weapon" which would drive the Red Army back. $^{51}$ Hans von Lehndorff, a doctor and surgeon from Allenstein, East Prussia, just east of Danzig appeared also to have been convinced by the idea of Hitler's secret weapon. Lehndorff may have also been specifically influenced by the sadistically loyal Gauleiter of East Prussia, Erich Kohl, who preached of a "wonder-weapon" that would save the

\footnotetext{
${ }^{50}$ Nitschke, 71.

${ }^{51}$ Levine, 158-161.
} 
Germans of the east. ${ }^{52}$ Lehndorff wrote, "The Fuhrer has planned everything up to now and must have some definite reason for letting the Russians push so deep into our country." 53

Even though Hitler ordered Forster to hold Danzig to the last man, it would be too reductionist to contend that it was merely faith in Hitler and his ability to contrive a miracle weapon to repel the Soviets. Likewise, it is difficult to determine how widespread among the lay Danzig population the reportedly common belief was which asserted that even if Germany lost the war, Danzig would revert immediately to Free State status under international protection. ${ }^{54}$ Eyewitnesses to the events transpiring in the city in the winter of 1945 attributed fear of SS retributions for cowardice and noncompliance in the defense of the east rather than faith in Hitler or post-war international intervention by the Allies, as being far more likely causes of this continued sense of loyalty towards the Third Reich by the residents of and refugees in Danzig. Łajica Lewandowska confirmed this belief when she stated that bodies of Germans hanging from trees and lampposts were a common sight as early as January of 1945. This was a constant and morbid visual reminder of the fate that awaited Germans who did not remain loyal to Hitler. ${ }^{55}$

For Germans outside of Danzig, faith in Hitler and his secret plans of a counterstrike were quickly replaced by the grim reality of the rapidly approaching Red Army, who would pass through their areas first on the way to Danzig. For Lehndorff, any hope he had of a secret weapon disappeared with the arrival of the Red Army in Allenstein.

\footnotetext{
${ }^{52}$ Hans von Lehndorff, Token of a Covenant: Diary of an East Prussian Surgeon, 1945-1947, trans.

E.Mayer, (Chicago, Ill: Henry Regnery Company, 1963), 5-12.

${ }^{53}$ Ibid, 13, 39-40.

54 Tighe, 185.

${ }^{55}$ Lewandowska interview.
} 
He reported being woken by a loud noise: "It sounded as if many heavy trucks were standing around the building with their motors running uninterruptedly...this could only mean the end." Lehndorff chose to escape north to Königsberg rather than west to Danzig, but described the evacuation from his home as a journey in which he felt that he was witnessing "the end of all the places that mattered" to him. Unquestioning faith and loyalty to the Fuhrer in the most desperate of situations certainly caused excessive suffering and death for Germans at the end of the war. In Lehndorff's case, realization that he had been led to believe falsely that Hitler would protect his home is manifested in a profound sense of victimization through loss of Heimat.

The problem for refugees located in the eastern and southern areas of the Gau of Danzig-West Prussia was that Soviet military strategy had devised a plan to push towards Pomerania from the south, as well as from East Prussia, in an effort to cut off any land escape from the Danzig region to the west. The cities south and east of Danzig, such as Elbing, Marienwerder, and Marienberg were where the German 2nd Army made a last ditch effort to keep the Red Army from driving towards the Pomeranian coast. Many Germans in the east must have known that their window of opportunity to escape to the west by land was closing fast and that desperate measures were needed in order to get to Danzig. The testimony of a Major Jänecke of the Wehrmacht Medical Corp, who was dispatched from Danzig south to Marienwerder, reported harrowing images of refugees bent on escaping by land before it was too late. Jänecke wrote, “....the roads were so congested that for a time we tried to make headway across country and along field paths. But even there, refugee treks were blocking the way. People of all kinds, on foot, leading 
fantastic vehicles, stragglers-on in an indescribable ghostly procession." ${ }^{\text {56 }}$ Despite difficult conditions, endless delays, and disease, refugees located in the south of the Gau of Danzig-West Prussia were willing to endure extreme conditions to escape to the Reich by land.

For Germans in East Prussia, escape by land to Danzig was made even more difficult than for their southern counterparts, by virtue of the geography of the Baltic coast. By the last week in January it was becoming extremely difficult and dangerous for refugees from the east Prussian coast to escape by land to Danzig except via the Frisches Haff, a long strip of land that ran under frozen water parallel to the Prussian Baltic coast, followed by the Nehrung road, both east of the city. These were places of memory where East Prussian refugees experienced and witnessed great suffering to reach the city. Danzig's myth as a safe haven certainly motivated many East Prussian Germans to undergo such perils. Lore Ehrich wrote in 1946 and 1947 as an expellee in West Germany, of her experience in escaping East Prussia with her family via the frozen Haff and the Nehrung. She stated, "Danzig was...the goal laid down for refugees. There we were to receive, clothes, coupons, and private billets." ${ }^{57}$

It is estimated that over half a million people fled over the icy and treacherous Haff to Danzig in late January and early February. ${ }^{58}$ The Haff had been defended tenaciously by the remnants of the German 2nd Army in retreat from the south and east. Ehrich and her family decided to flee to Danzig from their home in Sensburg, East Prussia after the Red Army arrived on 28 January. Forced to make the journey by night, Ehrich, her family, and fellow refugees traversed the Haff which was lit by flares from

\footnotetext{
${ }^{56}$ Tighe, 186.

${ }^{57}$ Schieder, 135-142

${ }^{58}$ Ibid.
} 
the Luftwaffe. She described images of horses, wagons, and people, who had fallen into the ice and frozen. Crossing the Haff, which is about ten miles long, took two days because the refugees had to avoid Russian bombers and fighters who tried to strafe and detonate the ice so that it would break. The images of the Haff would be followed by another space of severe traumatic memory right afterwards, the Nehrung road, which connected the southern end of the Haff with Danzig's eastern suburbs. "Oh this awful road!" recalled Ehrich as she described the poor conditions, deep mud, frequent halts and delays, corpses by the side of the road, and an endless column of refugees. Finally, Ehrich and her family reached Dirschau, on the outskirts of Danzig where she had to threaten suicide in order to convince an SS officer to feed, clothe, and let her and her children bathe, and then get them on a train to the city. ${ }^{59}$

Ehrich's account displays the threshold of suffering many eastern Germans were willing to confront and endure to reach Danzig. Rumors of its safety, provisions and access to the sea certainly must have contributed to motivating thousands of refugees such as Ehrich to go to such extremely dangerous measures such as to travel the Haff and the Nehrung road, as well as to threaten suicide, in order to reach the city. Upon reaching Danzig, Ehrich and her family were taken in by relatives for a few weeks before boarding a boat for Denmark. As a displaced person, Ehrich found the situation in Danzig at the time to be stable and was comforted by the fact that "after all we had been through, the few air-raids and the going down into the cellar was a trifle." ${ }^{, 60}$ Ehrich's sentiments reflected a general trend among both city residents, as well as those who had survived the trek to Danzig, that the city was safe for the foreseeable future.

\footnotetext{
${ }^{59}$ Ibid.

${ }^{60}$ Ibid.
} 
A sense of victimization by German refugees runs strongly through statements of the pandemonium in trying to escape from Danzig to the west by land. One teacher from Zoppot by the name of Ilse Kohl made the decision to leave Danzig on New Year's Day. Already the scene in and around the city had become chaotic as it took her and her family five hours just to get from Zoppot to Danzig Central Station, a train-ride that would normally take minutes. Ilse was then put on military transport that went first to Gotenhafen and then to Rostock, which took several days instead of several hours, during which time she and her family contracted scarlet fever. She wrote, "the guards kept saying that it was too dangerous for us to travel, that Polish engine drivers were taking trains full of refugees through the lines into the hands of the Russians...but a soldier near me said, 'don't lose your nerve, we are all in the same boat." teacher and soldier connect emotionally with each other by focusing on their own victimization during the evacuation of a region, where both no doubt had served to consolidate the Nazi regime. The memory of Ilse and this unnamed, but poignant soldier, while being transported find themselves representative of the east where Ilse had likely spread and engrained Nazi ideology and where the soldier enforced and fought for it. Their memories are also as traumatized refugees, expelled forever from their homes. They would serve as the advertisers of a sense of German loss and suffering in the east. By late January, it became more and more difficult to escape by land, making evacuation by sea the more prevalent means of fleeing the Red Army advance. Tales of Soviet acts of reprisal, violence, destruction, rape, and death brought by German refugees from the city, motivated thousands to crowd the docks and quays of Danzig, Gotenhafen, and Hela, despite the fact the rumors of Soviet submarine activity in the Bay of Danzig,

\footnotetext{
${ }^{61}$ Tighe, 181-182.
} 
the Baltic and the North Sea were widespread. Fear of the ravages of the Soviet onslaught, specifically the Red Army's propensity towards rape motivated thousands to pursue the dangerous avenue of evacuation by sea at any cost. The account of Countess zu Eulenberg, herself escaping from Neufahrwasser, a Danzig port in the western district of the city, provides a description of the scene on the docks and beaches of the city. On the beach through the snow all she could see was a horde of refugees, who had built a tent city out of blankets amidst the snow covered sand dunes, desperate to escape the city: “...the crush to get on board was just terrible...I saw a pram being squeezed out of all recognition by the pushing masses. One man fell into the water and there was nothing one could do in the crush...the Soviet guns and the Stormoviks strafed, tearing great holes in the waiting ranks of the refugees. But nobody moved, even death was less important than getting on board one of those boats. Babies were being used as tickets, being carried on board, and then thrown down again to be used as passports...some fell between the ship and quayside. It seemed not to matter..." $" 62$

The ship for which Eulenberg had witnessed such desperation and sacrifice to board was the Wilhelm Gustloff. Grand Admiral Dönitz ordered several large luxury liners to be activated to help get refugees and wounded soldiers back to the Reich on 21 January 1945, the largest and most well known being the Wilhelm Gustloff, named after a Nazi functionary who had been assassinated in Switzerland by David Friedlander, a Jewish student. ${ }^{63}$ Soon after sailing from Gotenhafen, the ship was sunk by a Soviet submarine off the Pomeranian coast on 30 January. It is estimated that over 7,000 people lost their lives, making it the greatest maritime disaster up to that point.

Captained by one Friedrich Peterson, the ship set sail poorly equipped for the rigors of the winter journey, the capacity of people aboard, and the threat of Soviet

\footnotetext{
${ }^{62}$ Christopher Dobson et al., The Cruelest Night, (Toronto: Little, Brown, \& Co., 1979), 24-25.

${ }^{63}$ Anthony Beevor, The Fall of Berlin 1945, (NY: Viking Pub., 2002), 51.
} 
submarine activity. Dönitz ordered the Gustloff be made seaworthy and capable of carrying thousands more than its original 1,465 passenger and 400 crew capacity although the dangers of such an evacuation along the Pomeranian coast were known. The ship left the docks with the escort ships Hansa, Hamburg and Deutschland on 30 January. The final passenger list aboard the Gustloff was 918 naval officers and men, 173 crew, 373 Women's Naval Auxiliaries, 162 wounded, and 4,424 refugees. While it is known that a large percentage of the refugees on board hailed from various locations in and nearby the Gau of Danzig-West Prussia, specific figures of how many actually were on the ship when it sank remain hazy because it stopped at Hela before setting out into the Baltic, to pick up approximately a thousand more refugees. ${ }^{64}$ Dönitz and the staff who helped him plan the operation had little choice in planning the ship's navigational route, other than to hug the coast, as the deeper waters were strewn with mines, yet the planning team failed to arm the Gustloff or its escort ships or adequately equip her with enough emergency life boats and preserves for all on board. ${ }^{65}$ Poor planning of the mission put pressure on the crew of the ship to perform and execute precisely in the event of an emergency situation. ${ }^{66}$

Alexander Marinesko, the commander of the Soviet S-13 submarine, is the Soviet captain credited with sinking the Gustloff. Marinesko's documented actions during the sinking of the ship, as well as his own memory of the hunt for the Gustloff display hate for the Germans. While the ship was carrying German military personnel, thus making it a legitimate target, sinking the Gustloff and killing innocent civilians was for Marinesko more than a mere assignment to destroy any ship suspected of coming to supply or

\footnotetext{
${ }^{64}$ Dobson et all, 83-84

${ }^{65}$ Ibid, 83-84

${ }^{66}$ Ibid, 67-70.
} 
leaving to evacuate the pocket of German troops holding out in the east. The Soviet literary journal Zvezda published Marinesko's war time experiences several years later. Marinesko wrote, "We were prowling up and down the fascist lair. But the dogs wouldn't come out and fight. I decided that next day I would take the war to them, get a fix on the Hela lighthouse and sneak into the Danzig Bay itself..."67 Marinesko had a reputation for being a heavy drinker when on land, but a sober minded, ruthless, and loyal Soviet comrade when at sea, who hated all Germans and the suffering their armies had brought upon the Soviet Union. It took the S-13 about two hours to catch up with the Gustloff, undetected as the ship's radar had frozen. As the Gustloff reached the waters near the Stolp Bank, the S-13 fired three bow torpedoes on the boat's port side, all of which found their mark. Reportedly, Marinesko ordered that the submarine stay, so that he could watch the ship sink, despite the fact that he knew the Kriegsmarine would soon send re-enforcements, a decision which no doubt put his submarine and its crew in jeopardy. Marinesko later torpedoed the Steuben, claiming another 3,000 wounded and terrified Germans from the east. The man himself is responsible for the deaths of around 10,000 Germans. ${ }^{68}$ Marinesko's actions, when juxtaposed with his statement above, certainly suggest a vendetta he felt he was enacting against the Third Reich and Germans from the east. He expresses a general sentiment branded into the Soviet officer corps which saw all Germans as "fascist dogs," who needed to feel the ravages of war brought upon their soil and seas, just as Soviet memory experienced during the German invasion of the U.S.S.R earlier in the war.

\footnotetext{
${ }^{67}$ Ibid, 93.

${ }^{68}$ Ibid, 98-101.
} 
While Marinesko's memory of the sinking of the Gustloff seemed to focus on a vendetta for Soviet victimhood, German memory of the events at sea that night display a sense of German victimhood, which completely ignored Soviet suffering. After the explosions, the scene onboard the Gustloff must have been one of pure panic and pandemonium, in total darkness and windy minus eighteen-degrees Fahrenheit weather. Many survivors reported that the ship's crew, rather than try and save peoples' lives, caused more to drown through ineptness in handling an emergency situation, as well as through their own sense of self-preservation. The first thing Captain Peterson ordered was to try and seal up the ship's leakage compartments. This trapped wounded soldiers and refugees below deck to drown. After failing to seal up the gashes in the ship's side, Peterson himself escaped to a lifeboat. Many of the ship's crew immediately decided to shirk their duties and jump aboard lifeboats to save themselves, even though an order had been issued to allow women and children to board the lifeboats first. Reportedly, one lifeboat that could have held fifty, hit the water with twelve sailors. ${ }^{69}$ There were also reports of armed sailors aboard lifeboats who clubbed or shot at swimmers trying to board their boats, for fear they would capsize or tip. The Admiral Hipper responded to the Gustloff's SOS signal, itself transporting 1,377 refugees and 152 dock workers to Kiel. At the last minute, the Hipper's captain received word that Soviet submarine activity was still threatening the scene of the sinking Gustloff. The ship pressed onwards, causing many who were still alive in the water, to drown in its wake. ${ }^{70}$

German memory of the sinking Gustloff recalled that for many, suicide was preferable to drowning or freezing to death. Heinz Schoen, who interviewed survivors of

\footnotetext{
${ }^{69}$ Ibid, 105-111.

${ }^{70}$ Ibid, 123-124.
} 
the disaster after the war in West Germany, spoke to a sailor who had run below deck to try and save those who were trapped. He un-jammed a door, to hear a pistol shot and discovered, "...on the floor lay the bodies of a woman and a small child. In the center of the cabin was a naval officer holding a still smoking pistol while a terrified five-year old clutched his father's leg... ( I ) had interrupted on a family suicide pact."71 Other methods of suicide on board the sinking ship were recorded by Schoen. Engineer Officer Walter Knust stated that the deck of the boat was very icy and many stumbled and slid off the sides. Since it had been so hot below deck, the shock of coming outside to such cold conditions, often severely underclothed, caused many people who jumped or fell into the water to die on contact. ${ }^{72}$ Knust wrote that many who were aware of the deadly frigid conditions outside used the elements instead of a pistol to commit suicide: "When we got to the boat deck it was swarming with passengers. I saw some of them even take off their clothes before they plunged into the water and they must have died at once., 73

Descriptions and memory of the Gustloff's final moments also display a sense of German victimhood. The ship took just over an hour to sink and at the last minute an explosion in the engine room knocked the lights on the ship back on. ${ }^{74}$ Witnesses described the scene as a fully lit ship, shining onto a sea of frozen bodies floating in the water, mixed with screaming of those struggling on the surface who hadn't succumbed to hypothermia. Both Dobson and the other authors of The Cruelest Night, as well as Günter Grass have speculated that the image of the brightly lit Wilhelm Gustloff sinking into the Baltic amidst the screams of German victims is a metaphor for the ultimate

\footnotetext{
${ }^{71}$ Ibid, 111.

${ }^{72}$ Ibid.

${ }^{73}$ Ibid, 112-115.

${ }^{74}$ Ibid, 120
} 
failure and downfall of the Third Reich at large. These authors also note in their respective works on the topic of the memory of the sinking Gustloff that after the German U-boat T-36 surfaced to pick up survivors, sailors on board helped deliver several babies of pregnant women who had survived the sinking of the ship. ${ }^{75}$ German memory has highlighted this phenomenon of the survival of these newborns as symbolic of the inheritance of victimization in which they were the ultimate survivors of the Gustloff who would carry on the memory of the German maritime disaster at the war's end. While it is not known exactly how many people perished, it is know that 964 were defiantly saved, including these newborns. ${ }^{76}$ These survivors, who were both directly and indirectly victimized by this tragedy, would take their memories of the Gustloff and recreate it for German post-war memory at large, without considering why the ship was torpedoed. The case of the Wilhelm Gustloff is an instance where both Soviet and German memory of the war would focus on their own respective victimization. For Marinesko, sinking this ship was a way to achieve both a military objective, as well as fulfill a national agenda of Soviet retribution for the German war crimes in the U.S.S.R. Marinesko probably would not even have been in the position as the captain of the submarine, had he not possessed the nerve to order the torpedoing of a ship where thousands of innocent civilians would die. Likewise, it would be equally unthinkable to expect a German refugee aboard the sinking Gustloff, witnessing all the horrors disaster around them, to stop and consider that the root cause of such a tragedy stemmed from Soviet suffering, inflicted by Germans. Yet, post-war memory of this event by both the

\footnotetext{
${ }^{75}$ Ibid, 123-129.

${ }^{76}$ Ibid, 140.
} 
Soviet perpetrators and Germans victims forget that the Soviet Union had also been a victim and Germany a perpetrator of equally reprehensible war crimes.

Following the Wilhelm Gustloff tragedy, Nazi high command decided to discontinue any further evacuations on the 1 February, officially denying Danzig's already bulging refugee population an option for escape. Danzig's population fluctuated so much that any estimate during these days is bound to be skewed. However, refugees continued to pour into the city by the thousands. Historians estimate that by 8 February, there were $35,000-40,000$ refugees in the city, two days later this figure jumped to approximately $400,000 .^{77}$ By mid-February, it has been estimated, 1 to 2 million permanent residents and displaced persons were in Danzig. ${ }^{78}$ Hitler's edict to suspend further evacuations trapped many refugees in the city. Those refugees who were temporarily living in Danzig or awaiting departure must have interpreted Hitler's decision as a sign that the front had stabilized. This belief was in addition to the fact that even in February, Danzig was still certainly a safe haven in war torn Prussia by any standards. ${ }^{79}$

The decision making of the Fuhrer was no doubt highly compromised by dementia, stubbornness, and pride, especially when it came to Danzig, a place which he had gone to great lengths to bring back to Germany. The extent to which Hitler was in complete denial of the situation in the city is illustrated by the decision he made in midFebruary. He had already decided that all naval construction and testing in the bay had become useless and ordered submarine units around Danzig to be evacuated immediately to Lübeck. Yet, he had not officially reactivated refugee evacuation from the Baltic.

\footnotetext{
${ }^{77}$ Beevor, 49.

78 Tighe, 93.

${ }^{79}$ Schieder, 39.
} 
Köslin, in Pomerania fell on 7 March, officially closing the pocket and making all land escape from East of West Prussia completely impossible. ${ }^{80}$ Only then did Hitler order that Danzig's "Target Sanctuary" would be Copenhagen, Denmark. ${ }^{81}$ Hitler had refused to accept the dire situation there and only ordered the Luftwaffe to drop supplies minimally, which in many instances were looted by German soldiers. ${ }^{82}$

In order to promote survival, or to salvage something positive from the dire situation in Danzig, many individuals from across the spectrum of the German military and civilian sector, defied Hitler's orders and edicts. Refugees who had fervently believed in Hitler and his ability to repel the Red Army, seemed convinced at the war's end, whether by tales of trauma on land or sea at the hands of the Soviets, that Danzig's fate was sealed. Hitler's decision to halt all further evacuations was ignored by both the military leadership and the people trying to flee the city. The Kriegsmarine launched Operation Sonnenwende on 16 February in an attempt to rescue all wounded soldiers, refugees, and residents from the city in one fell swoop. On 21 February, 51,000 reportedly left the city. ${ }^{83}$

Realization of the city's fate, through traumatic events can be interpreted in two ways. First, it may be an expression of individual survival and profiteering motives, which are often related. People crowded the docks of Danzig, dressing as pregnant women, borrowing other peoples' babies, inflicting wounds on themselves, threatening suicide, or committing whatever extreme measure it took to get on board a boat. At the same time crime was rampant in Danzig. City officials, who were busy building defenses

\footnotetext{
${ }^{80}$ Tighe, 184-185.

${ }^{81}$ Beevor, 93-94.

${ }^{82}$ Ibid, 49.

${ }^{83}$ Ibid, 93-94.
} 
and devoting manpower to slowing down the Red Army advance, were no longer able to prevent widespread corruption, looting, and the emergence of a vibrant black market. ${ }^{84}$ The SS were on patrol with vigilance, willing to execute anyone who did bravely assume a role in helping to defend Danzig. Nonetheless, an overall decrease in authority and an increase in the overall awareness of the traumatic future that Danzig would eventually experience, resulted in a mentality of deterministic individualism, manifesting itself in extreme self-preservation and/or individual opportunism.

Second, defiance of Nazi laws, edicts, and behavior by Germans at the end of the war may be indicative of a mindset which sought to distance Danzig and its people from Hitler, Nazism, and overall guilt in the last months of the city's existence. Hans von Lehndorff had already witnessed this dynamic at his new post at a hospital in Insterburg where a nurse under him interpreted the advance of the Russians as holding at least one positive outcome. She assumed that all high ranking Nazis would probably fly away beforehand: "Thank God, we are rid of them! At least we can breathe freely!" woman clearly did not hold the Nazis in high regard anymore and that they were a foreign entity who would not be missed. Prior to the Russian ransacking of his hospital in late March, Lehndorff reported that all his co-workers had begun to prepare for the inevitable. "On a table in their dining room stood a photograph of Churchill and everybody was busy learning Russian words of welcome." ${ }^{" 86}$

Danzigers as well as lay Germans who were not native to the city seemed to show a specific resentment at the war's end for Nazi leadership. The testimony of Hans Gliewe, a refugee from Stolp in Pomerania, who had fled to Danzig, described trying in

\footnotetext{
${ }^{84}$ Tighe, 188.

${ }^{85}$ Lehndorff, 13.

${ }^{86}$ Ibid, 157.
} 
vain to find a shelter during an air raid: "We went from door to door looking for a place. Many people slammed the door in our faces when they heard we were from old German territory. They called us Nazis and blamed us for everything that had happened to Danzig. ${ }^{, 87}$ By singling out a Reichsdeutsche (Germans who had been born in or who had citizenship of Germany proper) such as Gliewe, Danzigers at the last minute had decided that they had never been part of the foreign German sphere in the first place and that being invaded and annexed in 1939 was something Germany forced upon Danzig. Denial of protection for people from outside Danzig and placing the burden of guilt upon their shoulders at the last minute may have been motivated by traumatic memory as well. By early March, reports, rumors, and eyewitnesses had appraised almost everyone in Danzig of the level of anti-German ferocity that should be expected, should the city fall. Fear of these reprisals ultimately had to have been the most significant factor for this last minute switch of allegiances, denial of guilt, and hostility towards the Nazi superstructure and its perceived agents.

The sinking of the Wilhelm Gustloff seems to be the most prominent military event in Danzig history and memory during the early months of 1945 . Yet, one of the world's worst maritime disasters to date is relatively unknown and forgotten outside of German history and memory. Günter Grass reminded the world of the events in his 2001

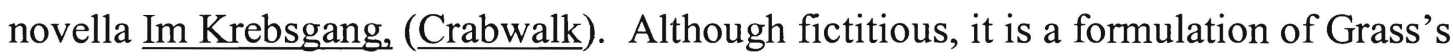
version of the events while finding a way to couch them into three generations of German history, as witnessed by survivors of the sinking ship and their descendents. Using the Danzig tragedy of the torpedoing of the Gustloff and its meaning for German memory,

\footnotetext{
${ }^{87}$ Tighe, 187.
} 
Grass's most recent work questions the evolution of this memory. In the process, Grass is critical of ways in which historians revisit and report events such as the sinking of this ship so symbolic to the victimization of Danzig's Germans. In Im Krebsgang, Grass goes well beyond the sinking of the Gustloff, using this tragedy as a platform by which to expose the hermeneutical problems of German history and memory fifty years after the events outside Danzig.

Im Krebsgang is the story of Paul Pokriefke, a journalist born the night the Gustloff sank. His mother Tulla was one of the pregnant women rescued who subsequently gave birth that night. Paul, representative of the 1960s generation of WestGermans that had rejected notions of German victimhood, had always been uninterested in his mother's victimization embodied in survivor culture, history, or memory passed down about the tragedy. Paul's son Konrad however becomes very interested in the topic, via the internet. Konrad creates a website and subsequently becomes obsessed with the assassination of Wilhelm Gustloff by the Jewish student activist David Friedlander. Konrad embodies the third generation of inherited German victimhood, continuing the memory of the tragedy. Paul, who was divorced and did not live with Konrad, can only watch as his son moves towards extreme right wing politics. Konrad uses his computer as both a research tool and an information and media outlet, all the while encouraged by Tulla's insistence that the memories of her experience not disappear. Konrad meets a fellow virtual historian in an internet chatroom who claims to be Jewish and is researching Friedlander. After weeks of debating each other over the internet on the merits of German perpetration versus Jewish victimhood, the two decide to meet face to face, where Konrad premeditatedly shoots and kills the other boy. In 
admitting his crime Konrad claimed to be revenging the assassination of Gustloff fifty years earlier. During Konrad's incarceration, Paul discovers that a website exists honoring Konrad's act and martyring his imprisonment. Like the sinking of the Gustloff, Konrad himself has become a part of the canon of German suffering and memory. The final words of the book ominously read," It doesn't end. Never will it end." $\$ 88$

First and foremost the title of the book, Im Krebsgang can be interpreted as a metaphor for doing any form of historical research and remembrance for a tragedy such as the sinking of the Wilhelm Gustloff. The last months of the war were highly confusing, complex, and controversial times to examine as they are possessed by multiple versions of German, Polish, Soviet and Jewish traumatic memory. ${ }^{89}$ Grass sums up the process his protagonist Paul must face in working through the memory of the events of his son's troubled life, his life, and the historical event of the sinking Gustloff:

"If I really have to settle my own historical accounts now, everything I messed up is going to be ascribed to the sinking of a ship...But I'm still not sure how to go about this: should I do as I was taught and unpack one life at a time, in order or do I have to sneak up on time in a crabwalk, seeming to go backward but actually a scuttling sideways, and thereby working my way forward fairly rapidly"90

As crabs walk sideways, Grass is commenting on the various angles one could approach and work through such topics, considering different versions of memory, from different time periods, held by various ethnic groups, each claiming a different memory of this incident. ${ }^{91}$ Grass, through his protagonist, is assuming the role of the historian and brings the methodology of research and scholarship, and the process of secondary memory into question.

\footnotetext{
${ }^{88}$ Günter Grass, Crabwalk, trans. by Krishna Winston, (San Diego, CA: Harcourt Inc. 2001), 234.

${ }^{89}$ Moeller, "Sinking Ships, the...," 179.

${ }^{90}$ Grass, Crabwalk, 1-3.

${ }^{91}$ Moeller, "Sinking Ships, the...," 179.
} 
Grass's imagery of the ways in which the right-wing had warped the memory of German victimization after the war portrays computer savvy skinheads debating in virtual reality. Paul begins to suspect his son's involvement in right wing political debate when he visits a neo-Nazi webpage and reads the debates that ensued in the site's chat-room. He views statements which seemed to reclaim or warp history: "more ludicrous than disgusting." Paul narrates that, "Soon battles raged between the right and left wings of the chatters. A virtual Night of the Long Knives took its toll." ${ }^{, 92}$

As Paul investigates his son's online activities, the protagonist is reminded how as a child, Tulla had tried to force him into the role of a historian and receptacle of the secondary memory of his mother's trauma. Paul also had to inherit a memory which his mother did not herself witness, but heard about afterwards, such as the particularly gruesome death of the Naval Auxiliary girls sleeping in the dry pool on the ship. As he narrates; "Because I have known, ever since the childhood my mother imposed on me, that the second torpedo struck the swimming pool and transformed its tiles and pieces of mosaic into deadly missiles..." ${ }^{93}$ Visual imagery of a scene so terrible seems to have caused Tulla to empathize with these particular victims within her own tragedy. Her own experience was so traumatic, that she assumed the role of an eye-witness because of this empathy. Paul, as the token fact gatherer, had to work through and live with such memories from this complex perspective. The role of the historian, which the neo-Nazis on the website had hijacked, was one which Paul had rejected all his life but was forced to assume in order to save his son's inherited memory.

\footnotetext{
${ }^{92}$ Grass, Crabwalk, 3-5

${ }^{93}$ Ibid, 61 .
} 
Grass levels a great deal of criticism at the right-wing and their incomplete and one-sided historical remembrance of German victimhood. At one point in the novel, Paul tries to approach Konrad when he had proof of his son's involvement in right wing activism. His son replied, "I'm doing historical research." "94 For Grass, the role of a historian of German suffering in Crabwalk, as in post war Germany had been championed by right wing revanchism, arm chair historians, and troubled teenagers searching for identity on the internet-all of whom had attached themselves to the memory of German victimization during the war's end. Grass uses Konrad's sudden interest in the trauma Grandma Tulla experienced, as an example of this version of history which only focuses on crimes against Germans and not their guilt. Proper scholarship which had worked through the event of 30 January 1945 would have considered that in many ways German crimes had indirectly caused the Gustloff to be torpedoed and sunk. ${ }^{95}$

In $\underline{\text { Im Krebsgang, Grass specifically addresses the shortcomings of Christopher }}$ Dobson's, John Miller's, and Ronald Payne's study of the Gustloff tragedy: The Cruelest Night. This study was written by a group of British historians in 1979, twenty-two years

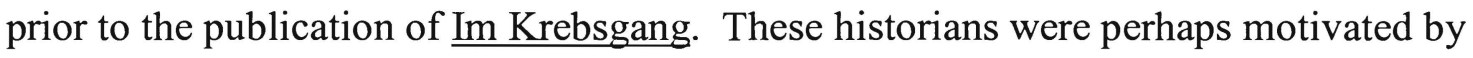
the lack of serious study on the topic, and decided to take Schoen's interviews, documents available from both Berlin and Moscow, as well as other accounts and write the first complete secondary history of the tragedy. On the Cruelest Night, Grass comments that, “...written by three Englishmen. But even this documentation of the

\footnotetext{
${ }^{94}$ Ibid, 78

${ }^{95}$ Moeller, "Sinking Ships, the...," 172-174.
} 
catastrophe, which I must admit was written factually but too emotionlessly...It's all too impersonal; nothing comes from the heart. ${ }^{" 96}$

Grass's assessment of the The Cruelest Night, though a good secondary source full of factual names, dates, statistics, and descriptions, focuses on its overall banal, matter-of-factually, stoic, and at times boring history of the sinking of the Gustloff. For instance, the authors of The Cruelest Night spend some time working through the question of whether the torpedoing of the Gustloff could be considered a war crime. Although the study takes no clear stand on the question, it does point out and seems to agree with the findings of an investigation conducted by the Institut für Seerecht in Kiel after the war. The Institute had concluded that the hundreds of naval submarine specialists on board, as well as the non-registration of the Wilhelm Gustloff as a hospital ship made it a viable target for Marinesko. ${ }^{97}$

The idea of deserved death or historical justice against the Germans, as no doubt propagated by Marinesko and Soviet memory of World War II, would be very difficult to substantiate on a moral or logical level. To invoke a "serves them right" polemic, in the context of correct military behavior is too reductionist and does not properly work through the idea of comparing German losses with Soviet losses, both as a result of the war. Grass's historiographical comment and stylistic critique of Dobson, Miller, and Payne's work can be interpreted as a critique of traumatic history at large. Furthermore, Im Krebsgang is a general criticism of the ways in which historians have assumed the duties of reporting on and the format in which they present topics such as the sinking of the Gustloff, and other multi-layered traumatic memories.

\footnotetext{
${ }^{96}$ Grass, Crabwalk, 98.

${ }^{97}$ Dobson et all 1979, 141
} 
Another issue within the context of researching the Gustloff tragedy and German suffering that Grass pokes fun at is the use of accuracy of statistics, specifically death rates, and survival rates in setting the parameters of victimhood. Paul recalled that,"...Mother really had no idea by whom she was pregnant when she set out on the morning of January $30^{\text {th }} 1945$ with her parents, leaving Gotenhafen/Oxöft pier as passenger number seven thousand such-and-such." 98 Priority of memory is being analyzed here by Grass in terms of whether the memories of where and when Tulla boarded the ship are reliable or even important. This is juxtaposed with who Paul's real fathers is, which nobody knows to this day and are ultimately moot points. Grass also paints a scene of the docks near the Gustloff as being completely chaotic and any registry of those boarding was bound to be skewed. "You wouldn't believe the pushing and shoving, total confusion. In the beginning they were keeping a neat list-everyone who came up the gangway-but even the paper ran out..."99 For Grass, "numbers are never accurate, in the end you always have to guess...it didn't matter and it still doesn't."100 In Im Krebsgang, Grass raises a number of general questions pertaining to the role, reliability and shortcomings of the historian/fact finder of victimhood and traumatic memory. Why remember the Gustloff within the context of the trauma during the end of the war brought upon the city of Danzig and its population? Is this tragedy significantly part of Danzig history? Konrad Pokriefke felt that as the agent of historical reportage, "any strand of the plot having to do directly or loosely with victimization of Germans fleeing from the city of Danzig and its environs should be (his) concern."101 According

\footnotetext{
${ }^{98}$ Grass, Crabwalk, 18.

${ }^{99}$ Ibid, 109.

${ }^{100}$ Ibid, 109-110.

${ }^{101}$ Ibid, 79.
} 
to Grass, German memory through research and recreation of victimization symbolized by a maritime disaster is inherently flawed. That to research traumatic events at the war's end, no matter how disconnected to these events Germans actually were, they could not help but possess a sole version of that memory, which denied Soviet, Polish, or Jewish suffering. 


\section{The Destruction of Danzig}

As March of 1945 began, the citizens of Danzig were preparing to witness war directly for the first time in the city's modern history as the Soviet $1^{\text {st }}$ and $2^{\text {nd }}$ Armies pushed eastward and northward from Pomerania and Elbing respectively. By then, Danzig bulged with refugees and wounded soldiers from the east, each with their traumatic memories of Russian assaults in other eastern German territories. The memories of Danzig Germans of these final days of the city's existence would focus on their own victimization. This victimization was manifested through stories of rape, murder, robbery, and destruction which saturated the city, causing a pre-traumatic terror syndrome to occur before the Russian armies approached. As the Red Army closed in on Danzig and its suburbs, the Germans in Danzig displayed reticence both to defend their city, as well as to carry out the scorched-earth policy demanded by Hitler for Gotenhafen/Gdynia in the face of certain defeat. Danzigers' sense of wartime victimization was confirmed with the appearance of Russian troops in the city. Upon taking the city, the Red Army brought the rumors of their terror to life in the streets and basements of the city. The Russians would force Danzigers to witness the destruction of their city as an object lesson for their co-operation and support of Hitler. However, the German authors of the statements and documents from the fall of Danzig, as a whole neglect their own participation in the Nazi regime in favor of a memory which made Danzigers the victims of the end of World War II. Additionally, Poles who still remained in the city experienced the ferocity of the Russian siege in much the same way as their German counterparts. In Danzig, memories of the destruction of the city would manifest 
themselves through Christian martyrdom at the hands of the atheistic Soviets.

Ultimately, the memory of destruction, violence, and rape during the last month of the city's existence as Danzig heralded its final hours and define those who suffered through

it.

All winter long Danzig stood in relative safety, but it had been flooded with refugees from East Prussia and the Baltic states fleeing the invasion of the Red Army. Even before there was any real Soviet military threat to the immediate Danzig region, the residents, refugees and displaced persons in the city began reacting to the impending loss of the war with apprehension and fear. One might call it a pre-traumatic stress syndrome, which military psychologist Philip Zimbardo describes, "that prolonged state of worry about one's vulnerability without any clear action to alter it can have a profoundly negative impact on our individual and collective mental health." 102 This appeared to be the case in Danzig, particularly in preparing a defense of the city.

Under these conditions, German authorities, including Gauleiter Albert Forster and General von Saucker, who was given authority over Forster in the task of defending Danzig, found widespread popular resistance to their demands that the city's current population of a million-and-half people participate in the defense. When the mobilization of Danzig's Volkssturm units began, city authorities found widespread reluctance to volunteer. Although the Elbing Volkssturm had been tenacious in the defense of that town, Danzigers seemed reluctant to participate voluntarily. Ads in the Danziger Vorposten newspaper on 8 March asked all former officers or men with any military experience to join their local units, as the city did not have sufficient volunteers to even

\footnotetext{
102 Philip Zimbardo, "The Political Psychology of Terrorist Alarms," American Psychological Association website, 2003, http//www.apa.org/about/division/terrorism.html.
} 
attempt a defense against the Red Army. ${ }^{103}$ This refusal may have been indicative of a general resistance toward defending an indefensible military strongpoint as well as an attempt by Danzigers to distance themselves from the Nazis at the last moment.

Danzigers' separation from the Nazi cause gained powerful re-enforcement after Nazi officials responded to popular reticence to defend their city from Soviet invasion by forcing Danzig's male residents to participate or die. Although most of Danzig's $9^{\text {th }} \mathrm{SS}$ Police Division had been evacuated to defend Berlin, Forster held onto 450 of these diehard Nazis, who went door to door pressing men and boys of all ages into service, shooting or hanging all who disobeyed. Most victims of this form of German suffering, as a direct result of Nazism, were males, some as young as fourteen or as old as eighty, many of whom were reportedly just going home to eat. ${ }^{104}$ The SS in Danzig established a makeshift tribunal in the Central Railway Station and often hung those found guilty from trees on prominent streets. One famous anonymously taken photo shows several men hanging in Danzig's Hindenburg Allee, with cards around their necks which read, "I hang here because I left my unit;" "I betrayed the Fatherland;" or "I am a cowardly traitor."105 Such arbitrary violence undoubtedly reinforced some Danzigers' perceptions that they were victims rather than participants in the German war effort. Łajica Lewandowska, who claimed to have seen many such bodies, marked as traitors, hanging from trees of various streets since January, remarked feeling sorry for the Germans, even though she and her family had been repressed by them. ${ }^{106}$ Even after the war, when Lewandowska recalled seeing German soldiers who had been captured and being marched away she

${ }^{103}$ David Yelton, Hitler's Volkssturm: The Nazi Militia and Fall of Germany, 1944-1945, (Lawrence, KS: Univ. of Kansas Press, 2002), 101.

${ }^{104}$ Tighe, 191.

${ }^{105}$ Ibid.

${ }^{106}$ Lewandowska interview. 
stated, “...it was kind of saddening, I felt empathy for them, they were a very proud race, they weren't sulking, they marched, they sang. They were still proud."107 For Lewandowska, witnessing the suffering of German Danzigers, that was reminiscent of the ways she, her family, and other Poles had suffered for the last decade, caused her to see her oppressors as fellow victims.

In neighboring Zoppot, this new sense of the Vistula Delta-Germans' sense of victimization sometimes gave way to confusion and tragically desperate solutions. As the Red Army advanced down the beach through Zoppot, General Rokossovsky had decided to drop leaflets all over the city to warn residents not to resist the Soviet invasion. In response, Hitler decided to also canvas the city with leaflets, which described Russian atrocities in detail and urged their readers to defend Danzig to the last. The most direct result of this competition for the cooperation of the city's citizens, through the saturation by leaflets, was high suicide rates in the month of March, particularly, though not surprisingly, among women. ${ }^{108}$

Animosity towards Poles and memory of the pre-war economic rivalry between the Free City of Danzig and Polish Gdynia dictated a different Nazi response to the Soviet advance on the port of Gotenhafen, a response which ultimately evoked feelings of victimization, even in those directly responsible for the war's violence. In this part of the greater Danzig region, German colonists and refugees who remained appeared not initially to have fallen in to the growing sense of victimization that marked the German inhabitants of both Danzig and Elbing. On 19 March, as the Red Army began its push upon the port city's suburbs shelling the main market in Gotenhafen, reportedly causing a

${ }^{107}$ Ibid.

${ }^{108}$ Tighe, 190-191. 
stampede of livestock throughout the city. The Germans who had not fled Gotenhafen knew that the city would certainly fall and proceeded to destroy as much of the city and the port as possible, so that it would not fall into the hands of the Soviets and to derail any future Polish rebuilding projects of the city. ${ }^{109}$ As mentioned in the previous chapter, Gotenhafen had been heavily germanized after the Nazi takeover of the former Polish Corridor, when ethnic Germans had been resettled into the former Polish port city of Gdynia. Although, most of the city's new residents therefore undoubtedly had little or no direct recollection of or relationship with the ways the interwar Polish government had used the city of Gdynia to compete against and surpass Danzig in economic prosperity, inherited memory infused with hatred for the Poles and their inter-war existence, spurred the city's residents to submit to Nazi orders to destroy Gotenhafen before it finally fell on 26 March. The Germans in Gotenhafen made a decision to perpetrate a vendetta-laden scorched-earth policy, designed to effect negatively Russian invasion efforts and future Polish rebuilding efforts. This decision indicates that not all of the Danzig region's German inhabitants submitted to either pre-traumatic stress syndrome or to feelings of victimization and therefore separation from the Nazi war effort.

Nonetheless, some who witnessed the destruction of Gotenhafen displayed a memory of the events which focused not on German retribution or perpetration of destruction and trauma but instead exclusively on German suffering. These witnesses, as a result, tended to further German ideas that they, no matter their ideological persuasions, had become the war's victims rather than its perpetrators and beneficiaries. A soldier retreating from Memel, who had participated in the scorched-earth policy in Gotenhafen, witnessed the birth of a child amidst the fire and explosions. He wrote, "If the birth of a

${ }^{109}$ Ibid. 
child is usually a joyful event, this particular birth only seemed to add to the general tragedy, the mother's screams no longer had any meaning in a world of screams, and the wailing child seemed to regret the beginning of its life." ${ }^{\prime 10}$ It is not unlikely that this soldier participated in other traumatic activities on the eastern front, as well as in the senseless destruction of a place which symbolized modern Polish economic prosperity and success. Yet, his concern at the time was for the tragedy inherent in the birth of a German baby, born in the midst of a battle zone and not for the trauma caused by the torching of Gotenhafen. The fact that the soldier has dubbed the place in which this baby has born as a "world of screams" underlines how even those responsible for the city's destruction saw themselves as victims of the city's incineration.

German Danzigers' sense of victimization grew during this last week of March as the Red Army began bombing, shelling, and employing other methods to weaken the city center's defenses and the morale of its citizens. As residents sought refuge in basements and air-raid shelters, a culture of terror emerged, even before those in cellars encountered Russian soldiers, which reinforced feelings of victimhood. While air raids had occurred in the city every night during the month of March, the night of the twenty-fifth was reportedly the worst in terms of Russian shelling and other methods of weakening the defense of the city and the morale of its residents. That night, the old wooden and halftimber buildings in Danzig's historic city center burned like kindling wood according to eyewitness testimony. One witness now saw the basement shelters as death traps, emphasizing: "We had to get out of the cellar because our house was on fire and we thought we would get crushed or burnt. We didn't want to get caught. When we got into

${ }^{110}$ Quoted in Beevor, 121. 
the open air we saw that everything was burning and the smoke nearly choked us."111 Gisela Lehmann, in contrast, described being forced into a cellar by the fires caused by the Russian siege. Her family's home had been destroyed in early March by Soviet shelling and as a result they had been living in someone's basement all month. Lehmann also recounted how the crowded basements appeared increasingly dangerous as the city burned: "We stayed there without interruption day and night and languished while being fired on constantly, in fear that we would almost be buried by the debris of the house above us. My younger siblings almost had to lie on top of each other in the cold basement since the few remaining houses were protecting thousands of people."112 Fires had forced Gisela Lehmann, her brother Siegfried, as well as their mother and friends into crowded basements that became fire traps in the midst of Russian invasion.

The parameters of fear and terror expanded when news reached basements that the Russian infantry had arrived. News of their arrival was especially harrowing to women of all ages who had heard rumors about how German women had suffered greatly at the hands of the Red Army in the east. Danzig women had been made privy to other refugee's tales of the Red Army's reputation for robbery and for sexual violence and soon realized they would become the war's next victims. Gisela Lehmann recalled that below ground, "The news came that Russians had reached us....The entire population inside the basement moved ever closer together and since they were only women and screaming children, this was a terrible sight to behold." 113 Gisela recalled that after the Russians had killed the German soldiers assigned to defend their basement, they immediately grabbed the women and girls and began raping them. Gisela's mother, who was pregnant

\footnotetext{
111 Tighe, 142.

${ }^{112}$ Lehmann, 2.

${ }^{113}$ Ibid.
} 
at the time, was also not spared this trauma even though she refused and fought against them, capitulating only when the Russians threatened to shoot her and her children. ${ }^{114}$

Anna Schwartz similarly remembered the sexual violence associated with the Red Army's arrival in Danzig. On 29 March 1945, the day Danzig fell, she, like most others had been living in an air-raid shelter "in fear of the future." Schwartz and the others in the air-raid shelter knew that although Russian firing and bombing of the city had ceased above ground, Red Army troops and tanks were proceeding through the streets of Danzig, killing, raping, and robbing. As Russian tanks drove around town with soldiers demanding that all Danzigers surrender through loudspeakers as Strauss waltzes playing in the background, Red Army soldiers who smelled of alcohol entered Schwartz's cellar calling "Urr! Urr!" and hastily robbed her. Fifteen minutes later another group of soldiers robbed her again. “...Meanwhile we heard the shrieks of women, who were being raped," she recounted. Ordered out of cellar by the Russians, and robbed once more, Schwartz, as she proceeded out into the street, noted how Soviet soldiers were now using the remnants of shelled buildings to take women captive and to rape them: "Paying no heed to death around us, we went past burning houses, Russian tanks, guns, and soldiers who absolutely wanted to drag us into the houses." 115

Soviet rape in Danzig was blind towards ethnicity and this blindness undoubtedly brought many German victims closer to the Poles they had formerly repressed, thereby increasing their sense of war-time victimization. Gerhard Nitschke, a Danzig Pole, who had witnessed and experienced Soviet violence more directly than Lewandowska during the siege of the city, described a 29 March rape and murder of his cousin in a basement

\footnotetext{
${ }^{114}$ Ibid, 2.

115 Schieder, 178.
} 
by a Soviet soldier: "scenes took place, which we already knew out of many other reports: looting, robbery of watches and jewelry and rape of almost all women, who were hauled up into the dwelling. For us, who were at the time still unsuspecting children, these were traumatic incidents; as result of the many rapes my fifteen-year-old [female] cousin is dead."116 Łajica Lewandowska, was lucky enough to have had fled Danzig prior to the Soviet invasion, escaping to a farmhouse near Putzig, well north of the city but experienced the suffering of the indiscriminate rape of Polish women vicariously. She recalled that after the war when Poles from Gdańsk reunited, they often asked one another questions such as "how many Russians raped you?"117 When we consider the accounts from Schwartz, Nitschke, Lehmann and Lewandowska we can conclude that rape was a shared suffering between German and Polish women in 1945. Many of the German families and women who were victimized sexually by Red Army troops didn't see themselves as perpetrators of the war because they were now suffering equally with Polish families and women.

Germans in Danzig, moreover, appeared incapable of seeing their victimization as war retribution and instead attributed it to the supposed racial and cultural inferiority of Soviet troops. Anna Schwartz, for instance, in the account above attributed Russian rapes to "Mongols" or "Asiatics." For her to claim that such racist language rooted German rape victims in Nazi rhetoric and thinking and thus stripping away Germans' innocence, overlooks the universality of these claims. On one level, Poles too, resorted to similarly racist language to explain why Soviet soldiers had raped family members. Nitschke, for example, described the soldier who perpetrated the burglaries and rapes in his cellar

\footnotetext{
${ }^{116}$ Nitschke, 81.

${ }^{117}$ Lewandowska interview.
} 
during Easter week as "Mongol.","118 The descriptions and recreations of the rape of women in Danzig universally, perpetrated in German and Polish testimony by Russians with so-called "Asiatic features," reveal a latent sense of racism within the statements of these young Germans and Poles. Although this racism could be the result of Nazi propaganda and indoctrination efforts, historians can assume that for many civilian Danzigers, who had been exposed to and supported Nazi racist ideology and who had limited to null experiences interacting with Soviet citizens, simply being around a racially foreign entity was shocking. The additional trauma of being raped by such a person must only have added to the shame and psychological trauma of such a violation and contributed to victims later efforts to transform the perpetrators of sexual violence into a racially different 'other.'

The context of racial sciences in the early part of the twentieth century, which placed great importance on the relationship between race and ethnicity as well as on their supposedly corresponding physical features, also undoubtedly defined some of the way in which German and Poles subsequently remembered their victimization. The overwhelming emphasis on racialist thought throughout Europe in this period can be seen in the reporting of British journalist Alexander Werth, The Times correspondent, who in spite of his best effort to attribute Soviet soldiers indiscriminate raping of German and Polish women to their linguistic limitations, nonetheless also informed readers that the military rapists were "Mongols." He rationalized the rapes of Polish women to the Allied coalition by explaining that because most of the Soviet soldiers were Asian, they did not speak Polish or German, much less proper Russian, and subsequently could not tell the difference between the two languages and thus raped Germans and Poles

\footnotetext{
${ }^{118}$ Nitschke, 81 .
} 
indiscriminately. Werth, though, also noted that Asiatic troops were the worst when it came to committing violence and rape; and thus also resorted to portraying a foreign, uncultured "other" in his reporting of the rapes. ${ }^{119}$

Religious differences also played an important role in many Danzigers' efforts to transform Soviet soldiers into barbaric "others," efforts which only furthered their sense of difference and victimization. Poles and Germans, for instance, tended to juxtapose their fervent Christian beliefs with Soviet atheism, and frequently attributed God's intervention for saving them from the Bolshevik horde. Nitschke, for example, included the traumatic memory of rape within the context of Christian faith in his testimony, noting that these events occurred over the course of the Catholic Holy Week, implying that the Soviets as Asians and as atheists had little respect for European Christian traditions and practices. "On Maundy Thursday...the first Mongolian soldier stepped into our cellar, till well into the early house of the morning on Good Friday."120 Siegfried Lehmann, who had watched Soviet soldiers rape his pregnant mother and sister, later asserted that his Christian faith had saved the family from subsequently being murdered by them. He claimed God had intervened on behalf of his family: "We only escaped being shot because I sang Church Hymns as I stood waiting to be shot." ${ }^{\text {21 }}$ His sister Gisela's account states that the Russians spared the Lehmann family because their Grandmother volunteered herself to be raped. ${ }^{122}$ To the obviously religious Lehmann family, Soviet destruction of Danzig's churches stood out as the most injurious and visually evident examples of Russian atheism and barbarity because it represented a

\footnotetext{
${ }^{119}$ Tighe, 199.

${ }^{120}$ Nitschke, 81.

121. "Siegfried Lehmann interviẹw," conducted by author, 2/15/06.

${ }^{122}$ Lehmann, "The developments leading..," 2.
} 
direct and visually evident attack on Christianity. The Russians, who had caught the Lehmanns and their fellow survivors, separated them into groups, and marched them up onto the Bishofs hills at the southwestern edge of Danzig where the "Stalinorgans" had been pummeling the city and the last German military strongpoints, to watch at gunpoint, "How our beautiful city was lit by fire and burnt to the ground. Danzig itself with all the wonderful churches, among others the large Marienkirche was destroyed."123

Like the rape of German women, forcing Germans to watch the destruction of their homes, as well as their places of worship, was a means for the Russians to gain psychological revenge for the SS and Wehrmacht having violated the U.S.S.R and its people during Operation Barbarossa. In the case of the Lehmann family, being forced to witness the destruction of Danzig was a violation, similar to rape in that it left a significant lasting memory, a permanent scar. More importantly, these traumatic memories show a sense of German victimization as both former residents of a now pulverized city and as Christians.

For those Germans in Danzig who did survive siege, fire, and rape, their uncertain future, with some facing imprisonment, others randomly executed, sometimes seemingly at random, and still others subject to forced labor, furthered their sense of victimization. Anna Schwartz was eventually taken from her air-raid shelter by Russian MPs to a farm where many Germans were fed, housed, and interrogated by an NKVD commissar to determine their wartime activities. "In a state of terror, we waited for what was to happen," she wrote. Anna was bounced around the former Gau to various internment camps. While in one at Langfuhr, several members of her original entourage were executed. "We assumed the Poles had accused these Germans of something," Schwartz

\footnotetext{
${ }^{123}$ Ibid, 3.
} 
explained. ${ }^{124}$ This assumption may have been correct, as the next day she was put on a train headed for a work camp in the South Urals and would not return to West Germany until 1948. Gisela Lehmann, who had been interned with her family in one of the many camps set up on the outskirts of the city, recalled that she and her family were lucky to have escaped because it subsequently became known that the prisoners from the camp, were almost all sent to Siberia. ${ }^{125}$ Deportations to hard labor in various parts of the Soviet Union were not an uncommon experience for many Danzigers. Army Group Rokossovsky would deport 55,000 from East and West Prussia for forced labor in the Soviet Union over the next year. ${ }^{126}$

According to the statements, testimonies, documents and literature from Danzig, Germans could only perceive, empathize with, and mourn the traumas inflicted on them by the Red Army. Yet, in some instances, their latent sense of duty and belief in Nazi ideology and order caused German Danzigers to participate in SS reprisals and scorched earth policies. The worst manifestation of German suffering, which appears to be rape, seems to have been exacerbated by notions of Nazi racism against Russian soldiers with Asian features. German victimization by the trauma which rained down upon Danzig in March of 1945 also manifested itself in a desire by Danzigers to find ways to separate themselves from Nazi collaboration, often through a relapse into religious fervor in which victimhood was defined by both civic pride and religious devotion. However, this dynamic as described above was not untainted by Danzigers' acceptance of Nazi ideology. Ultimately, the complete destruction of the city of Danzig left those Germans

\footnotetext{
${ }^{124}$ Ibid, 179-183.

${ }^{125}$ Lehmann, "The developments leading..." 3.

${ }^{126}$ Schieder, 65.
} 
who witnessed and survived the siege with no identity other than that of traumatized survivors.

In post-war German memory, the brutality Germans experienced at the hands of Soviet soldiers during the Red Army's march to Berlin, particularly in the emerging Cold War era, propagated ideas in West Germany that the country's new citizens were not the perpetrators of World War II, but its victims. Not until the 1960s did a new German understanding of the Soviet motivations for their soldiers' brutality against Germans emerge. Introduced by Günter Grass in Die Blechtrommel (The Tin Drum), these ideas, which Grass contextualized in terms of wartime experience of Danzigers certainly recognized Soviet troops' ferocity. Particularly in the chapters titled "Ant Trail" and "Should I or Shouldn't I" he simultaneously suggested that while the suffering they inflicted on Danzig's Germans was terrible, it was the result of German support for and complicity with the Nazis.

In "Ant Trail", Grass acknowledges the suffering that Germans experienced at Soviet hands by recreating the culture of trauma that existed in the final month of the war and by recreating the traumas that Soviet soldiers inflicted on Germans in the cellars and bomb shelters of Danzig during the last days of March 1945. "Ant Trail” as a title reflects German suffering as a result of the Russian invasion, with its connotations of long lines of refugees moving like ants along a cold and tumultuous trail, fleeing the Red Army in their migrations west during the winter and spring of 1945. Although Grass was not a direct witness to Danzig's trauma in March 1945, since he was wounded at Cottbus while serving in the Wehrmacht, he nonetheless also portrays the trauma many city 
residents experienced through imagery of refugees, soldiers, and tanks fleeing the fighting and of soldiers and Volkssturm men hung by the SS for cowardice and by depicting the fear and trauma of Danzig's cellar culture. Grass furthers his depiction of German victimization at Soviet soldiers' hands by portraying the experiences of a fictional group of Germans, the Matzerath family, in one of Danzig's basements. After the Russians enter the Matzerath basement, three of them immediately began to rape Lena Greff, a native Danziger and friend of the Matzerath family. The protagonist, Oskar Matzerath, watches as, "more and more calmly la Greff lay spread out beneath one after another of the three Ivans. When one of them decided to call it a day, my gifted drummer handed Oskar on to a sweating young fellow..." ${ }^{127}$ Lena's rape by the soldiers was certainly a common memory for German women in the east during the final months of the war, and thus Grass' inclusion of the rape emphasizes Soviet brutality in the most gruesome and realistic ways.

However, Grass departs from stereotypical notions of Soviet brutality during the war and rejects popular portrayals of Soviet perpetrators as atheistic uncultured barbarians from the "Mongol" east, preferring instead to indicate that the soldiers from different Russian nationalities participated in the rape of German women, regardless of their racial physical features. Oskar describes the Russians who enter the Matzerath basement as "perfectly normal Russians, slight racial mixture...six or seven of them appeared on the stairs with big eyes and Tommy guns."128 Oskar's textbook familiarity with the ethnic breakdown of the Red Army may be an allusion by Grass to illustrate the result of Nazi propaganda efforts in Danzig prior to the invasion. More importantly,

\footnotetext{
${ }^{127}$ Günter Grass, The Tin Drum, trans. Ralph Manheim, (NY: Pantheon Books, 1961), 393.

${ }^{128}$ Ibid, 392.
} 
Grass points out that the Red Army soldiers who participated in rape were not only Asian.

Grass also illustrates the randomness of the rape of German women in that not all of the Matzerath basement's female captives were victimized. The Russians do not rape Maria Matzerath, who is much younger, and presumably would have been a preferable victim over the old and sickly Lena, because she is cradling her son Kurt. Oskar states, "I had read in Rasputin that the Russian are great lovers of children. This, as I was soon to learn was perfectly true. Maria trembled needlessly. She failed to understand why the four Ivans who were not busy with la Greff left Kurt sitting on her lap instead of taking turns at it themselves..." ${ }^{\prime 29}$ When we consider this turn of events in Grass's story, with a similar description of witnessed trauma from the Lehmann family, it may very well be that Russians showed some sympathy to mothers. Lena's rape, as well as that of Siegfried and Gisela's grandmother, demonstrates that age, physical appearance and condition seemed to be relatively unimportant to the rank-and-file Red Army soldier in choosing victims of sexual violence.

This depiction of the Matzerath family's suffering at the hands of Soviet victimizers enables Grass to suggest that much of the responsibility for Soviet barbarity fell on Germans who were unable and unwilling to part with their Nazi past. Symbolically Grass makes this connection through his depiction of the family's patriarch, Alfred Matzerath. A Reichsdeutsche originally from the Rhineland, Alfred is an agent of Nazism who refuses to believe that the Nazi era has come to an end. As the city burned, he watched from the cellar in disbelief, “....as a child who can't make up his mind whether to go on believing in Santa Claus..." Denial quickly dissolves into fear, when

\footnotetext{
${ }^{129}$ Ibid, 392.
} 
Alfred realizes he still is in possession of a Nazi party pin, which, if discovered by the Russians, would mean certain execution, because as Oskar points out, "You didn't joke with the Russians." 130 Determined to erase any form of visual or material proof of his wartime politics, Alfred tries to pass the pin to the basement's female inhabitants, but Lena and Maria, both of whom are native Danzigers, distance themselves from the past once possessed by Alfred by refusing to take Alfred's pin. Oskar narrates that Alfred then decides to smash the pin into the ground, since neither Lena Greff nor Maria Matzerath would take the pin from him. ${ }^{131}$ Lena and Maria, both of whom are native Danzigers, distance themselves from the past once possessed by Alfred by refusing to take Alfred's pin. Oskar, though, refuses to allow Alfred to obfuscate the past by destroying the pin. He rescues the pin from oblivion, and when a Soviet soldier finishes with Lena, tidies himself, and picks up the diminutive Oskar, thinking him to be a young child, Oskar hands Alfred back his pin. Alfred grabs the pin from Oskar, and desperately tries to hide his Nazi association by swallowing the pin, an act which only makes those past associations obvious to the Soviet soldiers:

Little by little, fear took possession of Matzerath as he felt the emblem of his party between his fingers... But he wanted desperately to get rid of it, and despite the rich imagination he had shown as a cook and window dresser, he could think of no other hiding place than his mouth...That little move was enough to startle the two Ivans... They thrust there Tommy guns at Matzerath's belly and it was plain for all to see that Matzerath was trying to swallow something. ${ }^{132}$

Oskar, by reclaiming the party pin and giving it back to Alfred, refused to allow his presumptive father to escape responsibility for his Nazi past. One of the Russian soldiers, frustrated with the situation, shoots Alfred using an entire magazine of bullets.

\footnotetext{
${ }^{130}$ Ibid,

${ }^{131}$ Ibid, 391.

${ }^{132}$ Ibid, 393-394.
} 
Ultimately, Grass attributes the ferocity and excess of the soldier to Alfred's refusal to admit his responsibility for the war. Oskar, by reclaiming the party pin and giving it back to Alfred, causes the death of his presumptive father. Symbolically, it is a statement of blame and punishment of crimes, which focuses on the memories of German victimization.

Grass continues to place responsibility for the war squarely on the Germans' shoulders in next chapter, "Should I or Shouldn't I," a chapter in which the Poles begin to take over the city. Maria, now an embittered and traumatized war widow, is employed by Fajngold, a survivor of Treblinka concentration camp. Maria, consumed by German suffering during the war, shows Fajngold the most visible manifestation of that suffering, the corpse of Alfred, still in the cellar. By showing Alfred's body to Fajngold, a survivor of tragedy himself, Maria is equating the crimes committed against Germans during the war with the Holocaust. In this case, Grass presents Maria's actions as an allegory for the large numbers of people in post-war West Germany who felt that the two tragedies were comparable to one another. Maria keeps the body around long after Alfred's death, displaying it so that she too may possess victimhood, embodied in Alfred's corpse. But Grass also points out the absurdity of such conclusions in depicting Maria, while happy to work briefly for Fajngold, as only having sympathy for German suffering as opposed to Jewish suffering, evident in her failure to understand Fajngold's insanity and in her blunt rejection of his offer of marriage. She instead opts to be transferred with Oskar and Kurt to West Germany, where her notions of German victimization would be accepted and embraced. 
How well Germans have absorbed Grass' claims about German culpability for the end of the war in German cities in the east and for the subsequent victimization by Soviet soldiers is less certain. For instance, Oliver Hirschbiegel's 2004 film Der Untergang (Downfall), loosely based on the diary of Hitler's personal secretary, Traudl Junge suggested once more that Germans had been victimized by Soviet totalitarianism in the war's aftermath. The film, which highlights the last days of a number of high ranking Nazis, left to defend Berlin from the advancing Russian Army, depicts the widespread panic associated with the collapse of the Nazi state, with panic over the Soviet advance and loyalty to the old regime often leading to suicides of Nazi officials in Berlin. The film also depicts SS reprisals against pedestrian Berliners as well as a general trend of unnecessary German deaths in the defense of the city. Although, Hirschbiegel's film focuses on the German defense of Berlin, its last frames recount the fates of Berlin's Nazi defenders, with disproportionate emphasis on the leaders who came into Soviet captivity, such as General Wilhelm Mohnke and General Helmuth Weidling, both charged with Berlin's defense, or Otto Günsche, Hitler's personal adjunct, all of whom spent many years in Soviet captivity.

While the strengths of this film are its historical accuracy and a realistic depiction of a pre-traumatic terror syndrome caused by shelling, suicide and SS reprisals in Berlin in the late April of 1945, Der Untergang adroitly avoids the topic of the Holocaust. Furthermore, German perpetration of wrongdoing on anyone other than Germans in the film is non-existent with no mention whatsoever to any specific or general Nazi crimes in Eastern Europe or the Soviet Union, against either Jews, Slavs, or any other victims of the war. The very word "Jewish" is only spoken twice in the dialogue and only at the end 
of the film, does Hirschbiegel include a text frame which reads by the time of the official surrender on 7 May, 1945, “...the war had cost over 50 million lives. 6 million Jews had been murdered in concentration camps."133

While this film has nothing to do with the fall of Danzig, which occurred a month before the fall of Berlin and Hitler's suicide, it raises the issue of the memory associated with the Russian siege of German cities in the east. According to the statements, testimonies and documents from Danzig, Germans could only perceive, empathize with, and mourn the traumas inflicted on them by the Red Army. Yet, in some instances, their latent sense of duty and belief in Nazi ideology and order caused German Danzigers to participate in SS reprisals and scorched earth policies. In many ways, this film is an extension of this failure to establish a balanced discussion of German victimization and perpetration. Surely, at least some of those Nazi officials in and around the Berlin Führerbunker, or lay residents who lived in the vicinity of the Reich Chancellery had some levels of knowledge of Nazi crimes. However, the final scene of the movie shows an aged Traudl Junge, the former personal secretary of Hitler, express her innocence in not knowing about anything to do with the Holocaust until after the war. Is Hirschbiegel trying to convey the idea that a pre-traumatic terror syndrome was the cause of so many Germans being unable to see beyond their own victimization at the hands of the Soviets? Junge's post-war realization and ultimate acceptance of her participation in the Nazi regime, as the very last frame of the film is analogous to the film's overall approach to the topic of the Holocaust as almost an afterthought. Hirschbiegel's interest in many high ranking Nazis' Soviet imprisonment conveys the idea that for people in a city like Berlin or Danzig, a self-realization of German perpetration of the war could only occur in a

\footnotetext{
${ }^{133}$ Oliver Hirschbiegel, Der Untergang, (Constantin Film Produktion GmbH, 2004.
} 
post-war Europe, where the emerging communist authorities and governments would be most active and vociferous in carrying out de-nazification. 


\section{The Reclaiming of Gdańsk}

By 30 March 1945 Danzig was nothing more than a memory, both physically and politically. That day General Berling's $1^{\text {st }}$ Polish Army, which had helped the Soviets win the city, hoisted the red-and-white flag of Poland on the remains of city hall and announced the creation of the Polish provisional government for Gdańsk. The provisional government faced enormous challenges including how to rebuild a destroyed city and how to negotiate with Russian military officials to speed up wartime recovery. These challenges in turn were complicated by the city's diplomatic insecurity. As the rise of the Cold War left the city's new Polish occupiers without multilateral international security guarantees, Polish communist officials also struggled with how to recast the city's German past, for the needs of the Polish present. What would that mean in terms of immediate post-war trauma? How would Polish efforts to integrate Gdańsk into Poland impact perceptions of the city's past? How would these efforts subsequently be remembered by those Germans and Poles who experienced them?

What emerged from the rubble of Danzig in the year 1945 was the new city of Gdańsk. A place where Polish authority executed their claims to the region through a multi-faceted process of polonization. In the process, the often traumatic initiatives to effect this change mirrored those of the nazification programs of Danzig during the war and pre-war years. On the one hand, German memory of this period focused on sufferings inflicted against the German population which had survived the capitulation to the Red Army. On the other hand, Polish memory of the immediate post-war period 
justified the suffering inflicted upon Germans and their collaborators in terms of fulfilling the greater goals of reshaping Danzig into Gdańsk.

The Poles faced the overwhelming task of rebuilding the city, as Danzig had been almost completely destroyed. Elizabeth Clarke used the term "systematic" to describe the extent to which the city was reduced to rubble by the Red Army. Some of the few buildings which the Russians had spared included the East Prussian Fire and Life Assurance, the Danzig Police Headquarters, and the Danzig Prison so that the NKVD could examine records of ownership, criminal, and political archives, as well as police files from during the war. Ninety percent of all buildings, eighty-five percent of industrial plants, and thirty-five percent of roads were destroyed. Clarke quotes a recent Gdańsk tour guide book which stated that overall, ninety percent of the old city had been destroyed and that two to three million cubic meters of rubble lay where Danzig had once stood. ${ }^{134}$ These statistics, although rather impersonal and seemingly impossible to quantify, do indicate the enormity of the job the Poles had in rebuilding Gdańsk.

Gdańsk's now Polish city administration also inherited a city with a population ravaged by evacuation and war. The problem for the Polish government was that Gdańsk had suffered a severe population loss as a result of the Soviet invasion. Nearly a quarter of the city's population, including many Poles had fled the Red Army's advance and attack on Danzig. Another quarter of the city residents had been killed in the fighting. Entire neighborhoods lay empty and the reduced population was highly problematic for both rebuilding and reclaiming Gdańsk. ${ }^{135}$

\footnotetext{
${ }^{134}$ Clarke, 5-6.

${ }^{135}$ Schieder, 82-84.
} 
In addition to these challenges related to post-war reconstruction, Polish authorities faced another set of unique challenges in their accession of the city. The Poles shared authority with the Red Army and as a result their desire to rebuild and repopulate the city often appeared at odds with the Soviet authorities' demands to exploit what little remained in the city for Soviet ends. Soviet and Polish officials for example, clashed over the pace of Poles returning to their homes that had escaped war damage, with Soviet officials, according to the commander of the Polish civil militia in a report dated 30 April 1945, refusing to allow Poles to reclaim their former homes: "The Polish population, which came back to these residences, from which they had been evacuated by the Germans and even those, who wanted to return to their houses and dwellings, were not allowed to enter by the Soviet Authority."136

The tensions were exacerbated by the fact that all measures of the occupation were ultimately determined by the Soviets until later that spring; and they tended to place Moscow's demands for material reparations above the Polish reconstruction effort. ${ }^{137}$ To the Spoils of War Commission in Moscow, theft of goods was supposed to contribute to the rebuilding of the Soviet Union, which took precedence over the rebuilding of Poland. The Soviet military rank-and-file further desecrated the city even beyond the trauma of rape, as they were most known for their predisposition towards theft and robbery. Numerous accounts describe their specific interest in goods such watches, bikes, and machinery. For the rank-and-file, anything that wasn't locked down or guarded was fair game. $^{138}$

\footnotetext{
${ }^{136}$ Nitschke, 13.

${ }^{137}$ Schieder, 75-83.

${ }^{138}$ Tighe, 207-208.
} 
The Poles owed much gratitude to the Soviets for liberating them from Hitler and simply had to tolerate such behavior through the spring and early summer. The Polish communists also undoubtedly recognized that their legitimacy was painfully thin throughout Poland and particularly thin in Gdańsk. Polish communists had not enjoyed popular support in either the interwar period or during World War II under German occupation. Krystyna Kersten contends that as Russian occupation authority gave way to the Polish communist authority, Stalin's prerogatives were to allow the Poles to form a communist state with goals designed specifically to rebuild and reshape the future of Poland without simply mirroring Soviet communism. ${ }^{139}$ On the other hand, Norman Davies contends that Soviet political decision making was very active in forming the future of the Polish communist state. The assumption of Polish territories in the east, including cities such as Vilnius and Lwów as part of the shifting of Poland's borders westward, forced massive migrations to destroyed and largely abandoned cities such as Gdańsk. Davies contends that these population shifts provided the primary impetus for reconstructing a city like Gdańsk that had been a predominantly German cultural space for centuries. ${ }^{140}$

On another level, Poland's new communist authorities also encountered extraterritorial challenges to their administration of Gdańsk. Emerging tensions between the Soviet Union and its Anglo-American allies appeared to place in jeopardy the extension of Polish authority into the recovered territories, of which Gdańsk was a part. These formally German territories, stretched from the pre-1939 Polish-German border

\footnotetext{
${ }^{139}$ Krystyna Kersten, The Establishment of Communist Rule in Poland, 1943-1948, (Los Angeles: University of California Press, 1991), 173.

${ }^{140}$ Davies Norman and Roger Moorhouse, Microcosm: Portrait of a Central European City, (London: Random House, 2002), 411-412.
} 
westward to the Oder-Neisse River and south to the San River. They were incorporated into the new Polish state seemingly at the behest of allied concessions. Their incorporation into the post-war Polish state had been discussed at the Tehran conference in November and December of 1943 as a means of compensating Poles and for territory the Soviet Union had seized in the east in the first weeks of the war but subsequently had refused to relinquish. ${ }^{141}$ The Soviet authority's heavy political hand, particularly their refusal to accept the Polish London government-in-exile as the legitimate government for Poland and to militarily assist the insurrection launched in August 1944 by the exiled government's insurgents in Warsaw and the subsequent communist political putsch in Romania that same month, had left Britain's Winston Churchill, hesitant to officially endorse the western territories' inclusion into the Polish state. ${ }^{142}$ At Yalta, in January and February 1945, the Western Allies had suspended an official decision on this matter until a final peace conference. Thus, although the future Polish communist government had signed an agreement with the Soviet Union which outlined the territorial boundaries of the Polish state and included these so-called western territories in November 1943. The refusal of the western Allies to do the same and the absence of a post-war peace conference to provide mutual security guarantees for Poland's new western boundary meant that Polish sovereignty there was far from secure. Thus, for the Polish communist authorities the threat of western retaliation or of some form of German revanchism remained. ${ }^{143}$

\footnotetext{
${ }^{141}$ Herbert Feis, Churchill, Roosevelt, Stalin: The War They waged and the Peace They Sought, (Princeton, NJ: Princeton Univ. Press, 1957), 455.

142 Ibid, 415.

${ }^{143}$ Ibid, 519-529.
} 
The Poles responded to their rebuilding challenges and in particular their insecure hold over the western territories by embracing a stringent polonization campaign, reminiscent of the germanization previously promoted there during World War II. One of the first directives by the Warsaw government was to order Polish railroad workers from the former city of Bromberg, now called Bydgoszcz, to the city to repair and clear tracks between Gdańsk and Gdynia on 3 April, 1945. They simultaneously changed and repaired signs, which were now written in Polish. ${ }^{144}$ As already mentioned, the Polish communists had encouraged millions of Poles displaced by war and Soviet assumption of eastern territories to move west. Recent research by Sylwia Bykowska claims however, that by and large the Polish government did not encourage people to immigrate to a place like Gdańsk, preferring the displaced persons to settle in less appealing areas of the western territories. The Polish communists intentionally downplayed Gdańsk as a destination for refugees as they predicted it would be a popular destination without having to excessively encourage Poles from the east to resettle in the city. ${ }^{145}$ However, Bykowska claims that the immigrants who did come to Gdańsk came for economic opportunities, which the rebuilding of a port city would surely provide. She claims that many of these displaced Poles coming to Gdańsk, arrived with these false notions of its history, politics, and ethnic demographics. Their ignorance left these people with the impression that the city had a long and proud Polish history and identity. The refugees saw the city as home of the defenders of the Westerplatte Garrison and the Polish Post Office and were thus quite shocked to find the presence of Germans and a German past among the rubble. Their surprise manifested itself in animosity towards the

\footnotetext{
144 Tighe, 205.

145 Sylwia Bykowska, "Gdańsk-miasto (szybko) odzyskane," Biuletyn Instytutu Pamięci Narodowej, NR 910 (56-57) Wrzesień-Paździerknik 2005, 35-40.
} 
Germans who had survived the battle and remained in the city. ${ }^{146}$ These displaced Poles were eager to embrace a policy of strict polonization which the communists would subsequently enforce. The question for the Polish communists then, was how to create a propaganda campaign that would support claiming as Polish a traditionally German space such as Gdańsk.

The Polish communists moreover, were not above realigning history to meet larger national needs. Through propaganda efforts, they claimed that the newly acquired areas of modern-day western Poland had been historically Polish in the Middle Ages and thus, their incorporation into the post-war Polish state was an act of recovering what originally had been Polish. Even in places like Western Pomerania and Silesia, territories which had been a part of the Polish state of Mieszko I (960-992), this argument defied political realities, because Polish sovereignty had been relatively brief and had collapsed by 1181 in western Pomerania and 1368 in Silesia. But, communist efforts to include Gdańsk as a part of the "recovered territories" manipulated the territorial reach of the medieval Polish state because Gdańsk had not become Polish until 1454, long after the medieval Polish state that the communists claimed to have "recovered" had collapsed. ${ }^{147}$ Communist attempts to include Gdańsk into the historic medieval Polish state also worked to suppress the city's German-dominated history. In places in East and West Prussia, which had a stronger Polish presence this was easier and more justifiable. ${ }^{148}$ But, Danzig did not have a huge Polish presence in the modern period and had not

\footnotetext{
${ }^{146}$ Ibid, $40-45$.

${ }^{147}$ Tighe, 23.

${ }^{148}$ Norman Davies, God's Playground: a History of Poland, V.1, (New York: Columbia Univ. Press, 1982), 64.
} 
possessed significant Polish population since the medieval Polish state. ${ }^{149}$ Most historians agree that Poles had not made up any more than about five percent of the region's population prior to the war. Finally, including Gdańsk in the recovered territories denied the city's historical opposition and its economic competition with the Polish Republic in the interwar period. ${ }^{150}$ Part of this historical re-interpretation of history presented to the Polish public in propaganda campaigns as a consequence of the post-war need to embrace national unity. These manufactured notions of history to support a communist future was largely accepted by Poles from east and central Poland who had been displaced by the ravages of war and were forced to migrate. Thus widespread acceptance of a policy of reclaiming territories which would entail that Poland's traditional borders shift westward to support these migrations.

Even as the Poles embraced historical ideas that did not always apply to Gdańsk, the questionable international security of the western territories undoubtedly made them hesitant to completely erase the city's heritage through its most visually evident form: architecture. Part of the challenge in the rebuilding process of Gdańsk for Polish architects and engineers was to rewrite the memory of the city. For communist authorities in 1945, tying Gdańsk back into the Polish sphere through rebuilding efforts would justify annexation of the city without official international approval or historical validity. Their task was to build Gdańsk as a place that always had a strong Polish element, while being palatable and politically correct for a communist future, and at the same time making decisions that did not openly provoke western ire. A Polish tourism booklet of the city, produced in 1962 shows photographs of specific destroyed places in

\footnotetext{
${ }^{149}$ Ibid, 17.

${ }^{150}$ Kersten, 272.
} 
Gdańsk in April of 1945, juxtaposed with photos of the same places in 1962, completely rebuilt. No doubt written under the auspices of communist authors and censors the pamphlet includes a brief history of the city intended to try to justify rebuilding and reclaiming efforts by linking the city to a historically Polish past. The author offers as evidence, statements such as, "The very earliest relics-archaeological finds dating from the Tenth through Twelfth centuries, a testimony to the city's Slavonic past..." or "...just as in centuries gone by, Gdańsk owes its development today to the fact that it serves the Polish maritime economy..."151 By including photos of rubble from 1945, with photos of an aesthetically pleasing and bustling communist society in 1962 , the authors of the booklet wish to show more than how successful the rebuilding projects had been. The entire booklet is meant to demonstrate in a Machiavellian sense, under the guise of tourism, that the ends- successful modern Gdańsk- stands testament to the validity of the means- the Polish reclaiming initiative.

Evidence of Polish discomfort over the presence of Germans in Gdańsk can be seen in the ways they deprived them of food and then held them responsible for diseases plaguing the city and attributed to the Germans. Many reports indicated that in former areas of East and West Prussia, disease often caused by malnutrition was prevalent among the region's Germans as a national group. Because of their status as a defeated people, they had almost no access to food. One report stated that Germans in Gdańsk were preparing food with weeds and using fertilizer for salt. Gisela Lehmann corroborated these claims when she stated that "nothing was left for the remaining German people in any way." She and her family had to beg for scraps, as anything of

151 Jerzy Stankiewicz and Bohdan Szermer, Gdańsk, (Warsaw: Arkady Edition, 1962), 4-5. 
substance they had was usually stolen. ${ }^{152}$ Under these conditions typhoid fever was common, especially in the jails and interment camps which mostly housed Germans. Polish authorities however, blamed the Germans for being harbingers and propagators of disease and even went so far as to suggest that their removal from Gdańsk would end a typhoid epidemic there. The director of the Gdańsk Health Board suggested for example: "With the resettlement, even if not of the whole, but at least the largest part of the German population from Gdańsk, the epidemic could be completely subdued." 153

Another major challenge facing the Polish authorities was the place of Germans in a city whose future was to be Polish. The Poles immediately began to utilize the remaining Germans as a labor resource. Most of the Germans who had not fled from the Red Army and had survived the fall and destruction of the city, as well as the subsequent expulsions that spring and summer were designated for labor efforts in rebuilding the city and its infrastructure. Those who remained were categorized as "able-bodied" or "nonable bodied." A later directive produced by the Polish Social Security Commission at the Conference on Questions of the Evacuation and Co-Ordination of the New Settlement, on 22 September 1945 stated that any non-able bodied Germans, including those who rejected working for the state, were to be expelled. ${ }^{154}$ German labor was doing much of the actual bricklaying for the purposes of rebuilding Gdańsk and reclaiming the city into a Polish sphere of which it had belonged to earlier in the millennium, with labor representative of its more recent German character as Danzig.

Polish authorities, citing German responsibility for disease, ultimately expelled Germans from the city and from the country. Expulsions began in earnest from Gdańsk

\footnotetext{
${ }^{152}$ Lehmann, 3-4.

${ }^{153}$ Nitschke, 104, 107.

${ }^{154}$ Ibid, 99.
} 
to points westward well before the Potsdam conference in July and August of 1945 officially sanctioned expulsions. As early as 1 June, signs ordering Germans to leave were posted throughout the city. ${ }^{155}$ The Polish authorities were inconsistent in the notification of Germans designated for expulsion. In some instances prior to Potsdam, departure cards were mailed to Germans, ordering them to a specific train station for departure to the west. However, the Polish militia, particularly prior to the summer of 1945, were famous for forcibly and arbitrarily extracting Germans from entire rows of houses, giving them minutes to choose some belongings, before herding them to the trains. In many cases, expulsion was fairly voluntary and Germans co-operated fully with the militias, knowing that they had no future as Germans in Gdańsk. ${ }^{156}$ It is unclear how many Germans fled, emigrated, or were transferred out of Danzig prior to Potsdam, as sufficient records of this were not kept. ${ }^{157}$ The scope of the expulsions made it appear as if they were wholesale rather than selective in nature. Expulsion at the hands of the Polish authorities also did not seem limited to non-able bodied and sick Germans, but rather were random and targeted Germans indiscriminately.

After the 2 August, 1945 Potsdam Agreement stipulated legal and humane expulsion as a means of resolving ethnic strife in the region, almost the entire remaining German population of 100,000 in Gdańsk, not imprisoned was marked for expulsion. However, most witnesses indicate that there was certainly nothing humane about expulsions after Potsdam. Polish authorities in Gdańsk transported Germans in much the same way Germans had transported Jews and Poles to concentration camps or other points in the east. Gerhard Nitschke witnessed Polish militias systematically evacuating

\footnotetext{
${ }^{155}$ Schieder, 108.

${ }^{156}$ Ibid.

${ }^{157}$ Nitschke, 183.
} 
Germans street by street in Soppot in September. He reported that Germans were ordered to pack and were then taken to the train station in the evening, so that their expulsion would be done in secret. "There it became clear this was a raid concerned with the cleansing of the city," Nitschke remarked. He also noted that over 8,000 people were expelled from Soppot in August alone, including sixty sick and injured individuals from the German hospital there. ${ }^{158}$ The Lehmann family also was expelled in August. Gisela recorded that they were taken to the train station with similar abruptness, and placed on a: “...Transport of injured people back to the now occupied Reich. A filthy cattle car which contained a large number of amputees and very sick people was now to be our home for two weeks. During this time several people died."159

International media coverage of the trauma inflicted by these so called "humane" expulsions suggests a further similarity between post-war polonization efforts and wartime nazification efforts. German trauma during the expulsions revealed a dynamic of retribution against Germans and other expelled enemies of the state similar to German repression of Poles and Jews during World War II. Norman Clark, who reported on 24 August from Berlin for the British newspaper News Chronicle, testified that the polonization of Gdańsk was just as brutal as the nazification of Danzig had been during the war. The Berlin correspondent of the Times suggested in early September that Polish authorities had executed male heads of households before initiating deportation procedures, a move similar, of course to Nazi efforts to eliminate those who posed the greatest threat to Nazification: "A women recovering from typhoid had, she stated, seen her husband beaten to death by Poles and she had then been driven from her farm near

${ }^{158}$ Ibid, 183-184.
${ }^{159}$ Lehmann, 4. 
Danzig to work in fields." ${ }^{160}$ Clarke also noted that Polish authorities slowed transports, with some taking over a week to cross the Oder, with little food, water, or provisions and enduring constant harassment by Poles and the Red Army. This post-Potsdam trauma suffered by the expellees from Gdańsk spared neither adults nor children, healthy or otherwise. The Times for example reported an exposé about the arrival in Berlin of three orphans from Gdańsk, who were parentless and deported alone. The article read,

"These three German children are paying for the sins their fathers may have committed. They are 'displaced' orphans, turned out of Polish orphanage in Danzig and sent back to Germany in tightly packed cattle trucks, without medical care and almost without food. The Poles, many of whose children looked like these not long ago, are clearing all hospitals of German patients, no matter how sick. ${ }^{161}$

This dynamic of retribution to the very last against the Germans was manifested in other forms of trauma and repression against the expelled. Clarke noted that trains coming in from Danzig, full of expellees, also carried Polish bandits who stripped the expellees of valuables: "Poles, who sat apart, waiting for the next train to go out. Then they would board it, and going through the train, would force these unprotected mothers and women to give up any possessions of value, including watches and jewels. ${ }^{162}$ Continued violence, repression, and robbery remained a problem for those who, after already enduring so much, were forcibly transferred to the west.

As expulsion dropped in volume by late autumn 1945, the Warsaw government's new prerogative for cities like Gdańsk was to identify and investigate Poles suspected of collaborating with the Nazis as well as to decide if the remaining Germans had any future

\footnotetext{
${ }^{160}$ Ibid, 112.

${ }^{161}$ Alfred de Zayas, The German Expellees: Victims in War and Peace, (NY: St. Martin's Press, 1993), 109.

${ }^{162}$ Ibid, 111.
} 
or usefulness in the city. As the year 1945 came to an end, the Poles placed the rebuilding efforts and the need to retain skilled individuals, regardless of ethnicity, ahead of trying to de-germanize and de-nazify Poland. By 1946 however, few Germans remained in Gdańsk, with estimates suggesting that by this year only 6,000 Germans remained in the city, while 284,000 had been expelled since March of $1945 .^{163}$ Regional Verification Committees, also established in 1945, were to complete this final stage of polonization. The drop in the German population of the region suggests that their efforts were largely targeted at those Poles who had claimed ethnic German status during the war and at mixed ethnicities, such as Kashubians, Koznavians, and Masurians, who also had been privileged racially over Poles by the Germans.

The Committees soon found great difficulty in proving guilt based on the wartime Volksliste, since so many Poles had applied out of fear of imprisonment or expulsion and therefore, the lists could hardly be considered accurate. ${ }^{164}$ Subsequently, these committees used a number of tests to determine the "polishness" of those being investigated. ${ }^{165}$ Most of these tests by the Verification Committees were subjective and highly inconclusive. The Verification Committees, for example, investigated individuals by their last names and ethnic self identification. The accuracy of this method was questionable for the Polish authorities because of Gdańsk’s inherently mixed ethnic character. ${ }^{166}$ At the same time, altering one's name and ethnically identifying oneself in such a way that would fit into the racially homogenous goals of the new Polish state

\footnotetext{
${ }^{163}$ Federal Ministry for Expellee, Refugees, and War Victims Pub., Care and Help for Expellees, Refugees, Victims of Material War Damage, Evacuees, Prisoners of War and Civilian Prisoners, Repatriated Persons, Non-German Refugees, (Bonn, Germany, 1964), 9.

${ }^{164}$ Nitschke, 139

165 Ibid.

166 Tighe, 221.
} 
helped prevent expulsion for those Germans who wished to stay. Hans von Lehndorff's states in his memoirs that while he was working in a hospital forty miles south-east of Gdańsk after the fighting had stopped, many Germans in this region had begun to refer to themselves as "Masuren" in order to deny their true German extraction. This statement suggests, the Verification Committees throughout the former areas of East and West Prussia investigated Poles, Kashubians, Musurians and other smaller Slavic groups with the same vigor as Germans to determine possible wartime collaboration with the Nazis. 167 Problems in the standards determining the retention or expulsion of specific segments of the populations allowed for a certain amount of randomness and subjectivity in deciding who was fit to stay in Gdańsk and who was not. ${ }^{168}$

The bottom line for the Polish authorities in deciding who could be ethnically polonized was labor requirements, which stipulated that a certain amount of labor including Germans, was needed in the rebuilding process. At the Congress of Autochthones in November 1946 the chairman of the Ministry for the Recovered Territories, Władyłsaw Gomułka, stated; "We shall not give up one single Pole to the Germans, and we do not want among us Poles one single German."169 Gomułka and the Polish communists didn't want Germans, but had a broad definition now of who constituted a Pole. In other words, Kashubians, too, could be Poles, but Germans generally couldn't. This statement shows that by the end of 1945, a policy of population retention superseded expulsion, especially when one considers that by this time a million people had been determined to be Polish under Gomułka's tenure. The needs of labor and reconstruction had to taken precedent over establishing an ethnically pure and

\footnotetext{
${ }^{167}$ Lehndorff, 289.

${ }^{168}$ Nitshcke, 139.

169 Tighe, 221.
} 
collaborator free province of Gdańsk. Verification Committees served to both polonize the city as well as contributing to the higher prerogative of the Polish government to reclaim the city of Gdánsk under sometimes dubious pretenses.

The traumatic experience of the shifting populations, borders, and possession of the city of Gdańsk left an imprint on how subsequent generations of both Germans and Poles remember the polonization of the city. The trauma of Danzig's Germans and this post-war memory is best captured in the canonical fiction of Günter Grass. His work, as already discussed in previous chapters, shows both sorrow and acceptance of the post war settlement. Grassian memory of subsequent generations has accepted that polinization of the city was terrible, but necessary for the future stability of the region. Polish literature, after the fall of communism in Poland in 1989, became more liberalized and subsequently it became permissible to publish more complex accounts of memory of these complicated events following the capitulation of the city in 1945. A memory of traumatic events, shared by both Germans and Poles, revolving around one main issue: the validity of Polish claims to modern Gdańsk.

Stephan Chwin in his book, Hanemann, translated into English in 1995 as Death in Danzig, focused his story on the repopulation and reclaiming of the new of city of Gdańsk. This fictitious account provides a virtual biography of the trials and tribulations faced by Germans who were allowed or forced to remain in the city as well as examining the motivations, apprehensions, and guilt of those Poles who relocated to Gdańsk from other parts of war torn Poland. What seems most interesting about Death in Danzig in the context of examining the complex situation of population shifts and the claiming of 
space is Chwin's belief that it was ultimately correct for the Poles to take the rubble of Danzig and create the new city of Gdańsk. While Chwin is apologetic for the trauma afflicted on Germans in the city, he defends his opinion that the reclaiming of Gdańsk was ultimately justifiable.

The protagonist of Chwin's novel is a un-named young Polish boy who relocates with his parents from Warsaw to Gdańsk after the fighting. As he and his parents search for a suitable house to claim and move into, they realize the "omnipresence of a German past," manifested mainly in the changing of the names of places, signs still written in German, and objects left behind by those who had fled. ${ }^{170}$ Chwin's characters also embody a sense of guilt for inheriting spaces of atrocities. This guilt for the events which transpired at the end of the war in the city is embodied by the haunting remnants of Gdańsk's former residents. This Polish family happens to move downstairs into an apartment where Hanemann still resides upstairs, in the former district of Langfuhr, now renamed Wrzeszcz. As the protagonist narrates, “....as soon as Mama stepped into the hallway...she jumped back right away without really knowing why...Over the letterbox marked 'Briefe' was a copper plate, with names written in shiny slanting letters: 'Erich Schultz,' 'Wolfgang Bierenstein,' 'Johann Peltz."'171 The mother's fright may have been an allegory for guilt over the destruction of German Danzig and the evacuation of many of its residents.

At the same time, the material culture left by the Germans of Danzig is metaphorical for the traumas and injustices suffered by Poles in centuries past. Among the foremost remnants of German culture, discovered by Poles claiming new homes are

\footnotetext{
${ }^{170}$ Joanna K Stimmel, "Reading the Urban Time/Space: Danzig/Gdansk as a Transnational Memoryscape in Grass' Unkenrufe and Chwin's Hanemann." (2005 GSA Meeting), 3.

${ }^{171}$ Stefan Chwin, Death in Danzig, trans. by Philip Boehm, (San Diego, CA: Harcourt Inc., 1995), 72.
} 
the objects left behind. The objects of German Danzigers are a constant reminder of the traumatic past of the city. Yet, these objects' age and filth also serve to emphasize the ways in which the Germans who had owned them had subordinated Polish national desires. As the mother investigates her new home, the narrator writes, "She opened the doors to the mahogany chest, rattling the leaded glass planes. Among the cobalt glasses and ceramic jars labeled 'Pfeffer,' 'Salz,' and 'Zucker,' she saw a gleaming white oval tureen with a handpainted Chinese seascape-blue brushwork and brown-sailed junk-and a lid shaped like a pagoda. When she lifted the lid she left a fingerprint next to the Rosenthal emblem-a dark pattern on a film of dust, like a round postmark on an ivory colored envelope."172

These objects denote the sense of smug comfort embodied by nineteenth century German petty bourgeois material culture. As the mother investigates these objects representative of German cultural, social, and politically superiority, she notices their dustiness and uncleanliness. Chwin tries to capture the German repression of the Poles, during the time in which many of these artifacts were made, through the symbolism of a gilded, yet filthy material culture. These nice middle class objects are seemingly gilded by the filth of German crimes against Poles throughout history. ${ }^{173}$

No matter how much Death in Danzig focuses on the memories of Germans' past associations with the city, it also demonstrates Chwin's opinion that Polish reclamation of the city was justifiable. German culture in Danzig, Chwin reminds his readers had degraded Poles in the past and provided a justification for the post-war Polish settlement. Nor does Chwin question the moral and ethical dilemmas raised by the fact that Poles simply moved into houses abandoned by Germans. The Polish family in this novel had escaped the destruction of Warsaw to take part in the rebuilding and reclaiming of

\footnotetext{
${ }^{172}$ Chwin, 83.

${ }^{173}$ Shallcross, 119-12i, 125-127.
} 
Gdańsk in much the same way many Germans had fled from the destruction of the eastern territories and would eventually participate in the rebuilding of East and West Germany in the late 1940s and 1950s. ${ }^{174}$ So many Poles were homeless in the interior of Poland and had suffered through the trauma and violence of war. Chwin moreover justifies the seizure of his protagonists' German property, when Hanemann is rescued by Józek, the father of the protagonist, from being the victim of szabrownictwo (a Polish term meaning "looting" which was popular slang after the war in the east). Chwin may even be demonstrating his opinion on the issue of this form of latent guilt, by couching Hanemann's defense at the hands of Józek as being justification for his claim on the abandoned apartment. ${ }^{175}$

Stefan Chwin's characters no doubt feel a sense of guilt for the events that had transpired in the city; they ultimately assume and do not really question the role of new residents in the reclaimed territory. The reader has no way of knowing whether the protagonist and his family in Death in Danzig, are even aware of the historical exaggerations behind the idea of reclaiming Danzig, to become Gdańsk. However, the visual evidence of a German past embodied in material culture is blatantly obvious to this family. Chwin's memory of these events show both guilt for the actions of the post-war Polish government, as well as acceptance of their long term results, based on the need for Polish life to re-emerge in Gdańsk and Poland at large.

As this chapter has attempted to show, suffering in the new city of Gdańsk continued well beyond the capitulation of Danzig in March 1945. Polish authorities

\footnotetext{
${ }^{174}$ Ibid, 119.

${ }^{175}$ Ibid, 119-121.
} 
immediately realized that they were under the authority of another occupation force. Nonetheless, their goal was to reshape the future of Gdańsk and make it part of an emerging communist society. The appearance, population, and history of the city would all have to change. For those Germans who had survived capitulation, a period of disease, verification, and forced labor would eventually result in the traumatic event of expulsion or forced polonization. For the Poles, who felt after enduring so much, they had the right to reclaim Gdańsk, even if it meant continued suffering for Germans. Regardless of the political outcome of the city's re-alignment with Poland, the memories of this period are still shared and the debate continues on how future generations of both Germans and Poles remember the transformation of Danzig to Gdańsk. 


\section{Conclusion}

The reclaiming of Gdańsk for Poland created immediate trauma but also cast a long shadow over the memories of successive generations of Germans and Poles who had been victimized by the war's end. One question which remains germane to this day within the memories of both German and Poles who survived the trauma of Danzig's destruction and Gdańsk's re-construction was the overall justification of the post-war decision to allow the city to be reclaimed by Poland. The final question, in the interviews with Siegfried Lehman and Łajica Lewandowska, asked for their overall opinion of the post-war settlement in Gdańsk. Both responses were fairly typical considering the ethnicities and biographies of these two. Lehmann believed that the status of Free City should have been re-instated. When asked if he would move from Australia, where he has lived for over three decades, and return to his home if it were to revert to a Free City, Lehmann replied "No, I would not return as there would be too many bad memories...memories which should never be forgotten."176 To this question, Lewandowska demonstrated her peculiar understanding of American history by comparing the post-war situation to the American civil war, in terms of the stability the creation of a Polish city of Gdańsk would have on the future of the region. When asked what she thought of the idea to renew the Free State, Lewandowska emphatically replied "No, no, no! It has to be the way it happened. That's the way it happened...war is war, it was justified." 177

\footnotetext{
${ }^{176}$ Lehmann interview.

${ }^{177}$ Lewandowska interview.
} 
For Siegfried Lehmann, the violence he witnessed was so prominent a memory of his young life, that to live there again was inconceivable. Although he briefly lived in Cologne, Siegfried Lehmann moved away from the northern hemisphere completely, perhaps due to these memories. Lewandowska seems to have repressed her own traumatic memory of the war and its aftermath in Gdańsk, in positing the creation of a Polish city as something that was completely justifiable in the post-war world. While many members of her family have subsequently moved to the United States to escape communism and the memories of this traumascape, she herself has found peace with her memories and remains in Gdańsk to this day.

In the German case the city of Gdańsk seems to stand almost as an object lesson of the history of the war, a constant reminder of the foolishness and dire consequences of drinking out of Hitler's poisoned chalice. At the same time, the suffering of Germans from Danzig and many other cities and regions across the east, allowed subsequent generations of Germans in the west to focus on collective suffering, instead of collective guilt. Danzig had been considered a bastion of German economic and cultural achievement in the east and its loss to Poland was mourned by Germans. For Germans who suffered in Danzig/Gdańsk, the memories from this period conjure up images of death, execution, forced labor, displacement, evacuation, and inhumane expulsion at the hands of the Soviets and the Poles. The space of memory that is Danzig/ Gdańsk is not exceptional is this respect, as many other cities and regions are associated with memories of German suffering in the immediate post-war east. However, for those like the Lehman family that survived, all that remains of their identity as Danzigers are traumatic memories of war. 
In the Polish case, Gdańsk stands as the spoils of war earned in the name of generations of suffering under German domination in Danzig. The city was pulled into the emerging post-war Polish state with the help of propaganda, internal displacement, deliberate withholding of medical attention in the face of disease and starvation, which ultimately led to the evacuation of populations, and finally the Potsdam accords. For Polish memory, the acquisition of Gdańsk was justified for a long-standing history of repression, culminating in the Nazi takeover of Danzig and the Polish Corridor. Poland and its people had suffered the brunt of the atrocities of World War II, perhaps more than any other European nation, next to the USSR. Memory of Polish suffering dictated that by whatever means, the communist authority "reclaim" Gdańsk.

Even today, a divide exists between Germany and Poland on how to best remember the sufferings not only of Danzig/ Gdańsk but also of the German expulsions at the end of World War II. As German expellees insist on the commemoration of their suffering through the creation of a museum dedicated to exploring the expulsions, the Polish government has proved less than willing to acknowledge Polish responsibility for the expulsions. In August of 2005 the Polish government outright rejected the possibility of an Expellee center in Warsaw. President Alexander Kwasniewski believes that such a place would only serve to lessen the role of Germany's perpetration of World War II, stating that "our attitude on the center is negative." Supporters of the Expellee center, such as conservative German Chancellor Angela Merkel, are optimistic that it will be built instead in Berlin. ${ }^{178}$

However, an expellee center in Berlin would not be as significant in terms of its location and the possession of memory. Throughout the 1950s and early 1960s West

${ }^{178}$ Hardy Graupner, "Poland Rejects Berlin Expellee Center,” Deutsche Welle, 8/16/05. 
Germany had many such museums and exhibits which sought to bring recognition to the plight of German expellees and those trapped in the communist east. The fear of the Polish government is that such a sight would attempt to work through the memory of German suffering in Warsaw, where Germans perpetrated horrendous crimes, is not invalid. An expellee center would ask that the Poles recognize their own role as perpetrators of suffering, something they have been traditionally reticent to do. If an expellee center were to be built in Poland, would not a city like Gdańsk be a more suitable place? Erika Steinbach, the head of Germany's Union of the Expelled claims to hail from a town that was once near Danzig. More importantly, this city with its shared heritage presents itself as a place where the memories of sufferings associated with World War II are more closely shared between Germans and Poles than either Warsaw or Berlin.

The purpose of this analysis has been to try and create a portrayal of the “Traumascape" of Danzig/ Gdańsk in the year 1945. I have tried to define a traumascape as all the various facets of colliding, interwoven, and shared destruction, violence, fear, and retribution which contributed to both German and Polish memory of suffering in this particular region. Like a landscape, which focuses on one piece of the world and attempts to express its salient characteristics, a traumascape attempts to recreate a certain place's darkest and most horrific qualities. Why use Danzig/ Gdańsk as an example one might ask? Why not Königsberg/Kalingrad, or Breslau/ Wrocław, or any other place that would certainly fall into the category of a traumascape during the end of World War II? These examples, as well as the entire area that became Poland and East Germany, certainly have a claim to be studied as a traumascape. However, as stated in the 
introduction, there does not seem to be any significant work exclusively on the shared traumatic general military history and memory of Danzig in the modern era either in English, German, or Polish. Such a study certainly has not been written in the context of a collection of memoirs, documents, interviews, and personal statements of people who suffered through this time period, be they German or Polish, perpetrator or victim or any combination thereof.

While examining the documents, testimonies, interviews, fictitious portrayals, and memoirs pertaining to the suffering of the people living in Danzig/ Gdańsk, several larger issues were raised. Whether it was the period of germanization or nazification of Danzig, as well as polonization of Gdańsk, the history of the city of Danzig/Gdańsk also raises the greater questions of hermeneutical problems of World War II history. Finding a balance between suffering inflicted and received is the cardinal problem of German history for traumatic history specialist Dominick LaCapra, who argues that no matter how well one works through such multifaceted history, historical investigations such as this analysis invariably leave one oppressed group historically wronged. ${ }^{179}$ For LaCapra there may simply be no way to not tip the traumatic scales in favor of either German or Polish memory. With respect to traumatic memory, this city has represented different things to different people throughout history. Germans and Poles can all point to different periods of the city of Danzig when they were the war's victims. With the destruction of Danzig in 1945, the city of Gdańsk emerged as a place that sought to rectify all wrongs of the past, by re-populating and rebuilding in order to erase and move on from the past.

\footnotetext{
${ }^{179}$ Dominick LaCapra, Writing History, Writing Trauma, (Baltimore, MD: Johns Hopkins Univ. Press, 2001), 32-34, 44-45.
} 
It is my belief that in order to clearly work through the history, analyze, and hypothesize upon the shared suffering in this place of memory, historians must consider the tragedies of all the former and current residents of this place to be as Joanna Stimmel wrote, "contemporaneous catastrophes that must be discussed in reference to and reverence of each other." ${ }^{\prime 180}$ Only then can one proceed to the epistemological claim that considers Danzig and Gdańsk as completely separate entities. Based on political events, military and diplomatic strategy, as well as social movements in the year 1945, the exact moment when the city ceased to be Danzig and became Gdańsk is certainly debatable. Unquestionably, the year 1945 was the culmination of the city's troubled history, manifested in the death, rape, evacuation, imprisonment, political repression and expulsion of hundreds of thousands of people. It is my contention that the complex traumatic history of 1945 and the many terrible memories and experiences during that year are precisely what separates the existence of these two cities: Danzig and Gdańsk.

${ }^{180}$ Stimmel, 3. 


\section{$\underline{\text { Works Cited }}$}

\section{Primary Sources:}

Federal Ministry for Expellee, Refugees, and War Victims Pub. Care and Help for Expellees, Refugees, Victims of Material War Damage, Evacuees, Prisoners of War and Civilian Prisoners, Repatriated Persons, Non-German Refugees. Bonn, Germany: 1964.

Schieder, Theodor ed. Documents on the Expulsion of the Germans From EasternCentral Europe Vol.I. The Expulsion of the German Population From the Territories East of the Oder-Neisse Line. Bonn, Germany: Federal Ministry for Expellees, Refugees and War Victims, 1953.

Lehmann, Gisela. "The development leading up to our forced resettlement from our original homelands." Koeln-Nippes: May $4^{\text {th }}, 1950$.

Lehmann, Siegfried Klaus. Personal Interview, via email. February $15^{\text {th }}, 2006$.

Lehndorff, Hans Graf Von. Token of a Covenant: Diary of an East Prussian Surgeon, 1945-1947. Trans. by Elizabeth Mayer. Henry Regnery Company: Chicago, 1963.

Lewandowska, Łajica. Personal Interview translated through Kay Lewandowska, via telephone. March $14^{\text {th }}, 2006$.

Stankiewicz, Jerzy and Bohdan, Szermer. Gdańsk. Warsaw: Arkady Edition, 1962.

\section{Secondary Sources:}

Beevor, Anthony. The Fall of Berlin 1945. New York: Viking Pub., 2002.

Braun, Alexander. "History," Państwowe Muzeum Stutthof website. http://www.stutthof.pl/en/main.htm

Bykowska, Sylwia. “Gdańsk-miasto (szybko) odzyskane.” Biuletyn Instytutu Pamięci Narodowej, NR 9-10 (56-57) Wrzesień-Paździerknik, 2005.

Clark, Elizabeth M. "Reshaping the Free City: Cleansed Memory in Danzig/Gdansk, 1939-1952." Ethnic Cleansing in Twentieth-Century Europe, edited by Steven Vardy and Hunt Tooley, Social Science Monographs, Boulder. Distributed by Columbia University Press, 2003.

De Zayas, Alfred. The German Expellees: Victims in War and Peace. NY: St. Martin's Press, 1993. 
Davies, Norman. God's Playground: a History of Poland, V.1. New York: Columbia Univ. Press, 1982.

Davies, Norman and Moorhouse, Roger. Microcosm: Portrait of a Central European City. London: Random House, 2002.

Dobson, Christopher, Miller, John and Payne, Ronald. The Cruelest Night. Boston: Little Brown and Co., 1979.

Feis, Herbert. Churchill, Roosevelt, Stalin: The War They waged and the Peace They Sought. Princeton, NJ: Princeton Univ. Press, 1957.

Grass, Günter. "What Shall We Tell Our Children.” Danzig 1939: Treasures of a Destroyed Community. Jewish Museum, NY: Wayne St. Univ. Pub, 1980.

Graupner, Hardy. "Poland Rejects Berlin Expellee Center," Deutsche Welle News website, 8/16/05. http:/www.dw-world.de/dw/article/0,1681377,00.html?maca=encurrent_affairs_europe-105-rdf.

Harvey, Elizabeth. Women and the Nazi East: Agents and Witnesses of Germanization. New Haven, CT: Yale University Press, 2003.

Kersten Krystyna. The Establishment of Communist Rule in Poland, 1943-1948. Los Angeles: University of California Press, 1991.

Kimmich, Christopher M. The Free City: Danzig and the German Foreign Policy. New Haven, CT: Yale Univ. Press, 1968

LaCapra, Dominick. Writing History, Writing Trauma. Baltimore, MD: Johns Hopkins Univ. Press, 2001.

Levine, Herbert. Hitler's Free City: A History of the Nazi Party in Danzig 1925-1939. Chicago: Univ. of Chicago Press, 1970.

Mason, John B. The Danzig Dilemma: A Study in Peacemaking by Compromise. Stanford, CA: Stanford Univ. Press, 1946.

Moeller, Robert G. War Stories: The Search for a Useable Past in the Federal Republic of Germany. Los Angeles: Univ. of California Press, 2001.

Moeller, Robert. "Sinking Ships, the Lost Heimat and Broken Taboos: Günter Grass and the Politics of Memory in Contemporary Germany." Contemporary European History Vol. 12, Columbia Univ. Press, 2003.

Moeller, Robert. "Germans as Victims? Thoughts on a Post-War History of World War II's Legacies,” History and Memory. Indiana Univ. Press, 2005. 
Neander, Joachim. “The Danzig Soap Case: Facts and Legends.” German Studies

Review. Vol.XXIX, Num. 1, February 2006.

Nitschke, Bernadette. Vertreibung and Aussiedlung Der Deutschen Bevölkerung aus

Polen 1945 bis 1949. Munich: R. Oldenbourg Verlag, 2004.

Shallcross, Bożena. "The Archaeology of Occupation: Stephan Chwin's Writings on Danzig/Gdańsk," Framing the Polish Home: Postwar Cultural Constructions of Hearth,

Nation, and Self. Athens, OH: Ohio State Univ. Press, 2002.

Stimmel, Joanna K. "Reading the Urban Time/Space: Danzig/Gdansk as a Transnational Memoryscape in Grass' Unkenrufe and Chwin's Hanemann." Presented at the 2005 German Studies Association meeting.

Terry, Sarah Meiklejohn. Poland's Place in Europe: General Sikorski and the Origins of the Oder-Neisse Line, 1939-1943. Princeton, NJ: Princeton Univ. Press, 1983.

Tighe, Carl. Gdańsk/Danzig: National Identity in the Polish-German Borderlands Fiction. Pluto Press: London, 1990.

Yelton, David. Hitler's Volkssturm: The Nazi Militia and the Fall of Germany, 19441945. Lawrence, KS: University of Kansas Press, 2002.

Zimbardo, Philip. "The Political Psychology of Terrorist Alarms.” American Psychological Association website, 2003, http://www.apa.org/about/division/terrorism.html

\section{Fiction:}

Chwin, Stefan. Death in Danzig, trans. by Philip Boehm. San Diego, CA: Harcourt Inc., 1995.

Grass, Günter, trans. Ralph Manheim. The Tin Drum. NY: Pantheon Books, 1961.

Grass, Günter, trans. Krishna Winston. Crabwalk. San Diego, CA: Harcourt Inc., 2001.

\section{Film:}

Der Untergang. Directed by Hirschbiegel, Oliver. Constantin Film Produktion GmbH, 2004. 